Research Article

\title{
Molecular evidence for a recent demographic expansion in the puma (Puma concolor) (Mammalia, Felidae)
}

Eunice M. Matte ${ }^{1,2}$, Camila S. Castilho ${ }^{3}$, Renata A. Miotto ${ }^{4,5}$, Denis A. Sana ${ }^{6,7}$, Warren E. Johnson ${ }^{8}$, Stephen J. O'Brien', Thales R. O. de Freitas ${ }^{1}$ and Eduardo Eizirik ${ }^{2,6}$

${ }^{1}$ Laboratório de Citogenética e Evolução, Departamento de Genética, Universidade Federal de Rio Grande do Sul, Porto Alegre, RS, Brazil.

${ }^{2}$ Laboratório de Biologia Genômica e Molecular, Faculdade de Biociências, Pontifícia Universidade Católica do Rio Grande do Sul, Porto Alegre, RS, Brazil.

${ }^{3}$ Laboratório de Ecologia da Paisagem e Conservação, Universidade de São Paulo, São Paulo, SP, Brazil.

${ }^{4}$ Laboratório de Biodiversidade Molecular e Citogenética, Departamento de Genética e Evolução, Universidade Federal de São Carlos, São Carlos, SP, Brazil.

${ }^{5}$ Escola Superior de Agricultura Luiz de Queiroz, Universidade de São Paulo, Piracicaba, SP, Brazil.

${ }^{6}$ Instituto Pró-Carnívoros, Atibaia, SP, Brazil.

${ }^{7}$ Programa de Pós-Graduação em Ecologia, Universidade Federal de Rio Grande do Sul,

Porto Alegre, RS, Brazil.

${ }^{8}$ Smithsonian Conservation Biology Institute, Front Royal, VA, USA.

${ }^{9}$ Theodosius Dobzhansky Center for Genome Bioinformatics,

St. Petersburg State University, St. Petersburg, Russia.

\begin{abstract}
The puma is an iconic predator that ranges throughout the Americas, occupying diverse habitats. Previous phylogeographic analyses have revealed that it exhibits moderate levels of genetic structure across its range, with few of the classically recognized subspecies being supported as distinct demographic units. Moreover, most of the species' molecular diversity was found to be in South America. To further investigate the phylogeographic structure and demographic history of pumas we analyzed mtDNA sequences from 186 individuals sampled throughout their range, with emphasis on South America. Our objectives were to refine the phylogeographic assessment within South America and to investigate the demographic history of pumas using a coalescent approach. Our results extend previous phylogeographic findings, reassessing the delimitation of historical population units in South America and demonstrating that this species experienced a considerable demographic expansion in the Holocene, ca. 8,000 years ago. Our analyses indicate that this expansion occurred in South America, prior to the hypothesized re-colonization of North America, which was therefore inferred to be even more recent. The estimated demographic history supports the interpretation that pumas suffered a severe demographic decline in the Late Pleistocene throughout their distribution, followed by population expansion and re-colonization of the range, initiating from South America.
\end{abstract}

Keywords: conservation genetics, mammals, mitochondrial DNA, molecular time estimate, phylogeography.

Received: December 19, 2012; Accepted: August 16, 2013.

\section{Introduction}

The puma (Puma concolor Linnaeus, 1771) is a large felid that ranges throughout the Americas, exhibiting the broadest latitudinal distribution of any terrestrial mammal (Nowak, 1999). Pumas have remarkable dispersal capabilities (Maehr et al., 2002; Beier et al., 2003) and successfully

Send correspondence to Eduardo Eizirik. Faculdade de Biociências, Pontifícia Universidade Católica do Rio Grande do Sul, Av. Ipiranga 6681, prédio 12, 90619-900 Porto Alegre, RS, Brazil. E-mail: eduardo.eizirik@pucrs.br. occupy a diverse array of habitats, illustrating their potential to adapt to the breadth of environmental conditions occurring across the continent, from tropical forests and marshes to dry scrubland and cold Andean or Patagonian biomes (Redford and Eisenberg, 1992; Nowak, 1999). Pumas are solitary and territorial, with large home ranges. Females tend to occupy smaller areas and disperse shorter distances, thus being more philopatric than males (Logan and Sweanor, 2001; Maehr et al., 2002). Overall, the species' ecological flexibility and dispersal capabilities have 
the potential to induce broad genetic connectivity across large geographic areas, unless historical barriers have limited gene flow among populations.

Fossil evidence indicates that pumas were already present in North America 0.4 million years ago (MYA) (Kurtén and Anderson, 1980). In parallel, molecular data (Johnson et al., 2006) have led to an estimate of its divergence from the sister-species $P$. yagouaroundi of 4.17 MYA (C.I.: 3.16-6.01MYA), suggesting a much longer history as a distinct evolutionary lineage. The speciation event that separated these lineages may have occurred in North or South America, with the molecular dating estimate supporting the former, as it tends to predate the Great American Biotic Interchange (GABI) (ca. 2.5-3.5 MYA) and the implied colonization of South America by any felid (Woodburne, 2010; Eizirik, 2012). However, since the credibility interval of this estimate slightly overlaps the timing of the GABI, this issue is still not fully settled. Interestingly, Barnett et al. (2005) provided molecular evidence indicating that the extinct North American felid Miracinonyx trumani is the puma's closest relative, with a divergence time estimated at 3.19 MYA. This finding would support the hypothesis of a North American origin for the puma, with subsequent colonization of South America by this species, in parallel with that of the jaguarundi.

In a thorough study of puma phylogeography, Culver et al. (2000) assessed the current and historical genetic diversity present in this species, based on a large sampling of individuals from across its range. That study indicated that most of the 32 classical puma subspecies did not correspond to definable genetic units and reduced the number of recognized subspecies to six. Four of these subspecies were distributed in South America, indicating that most of the species' historical subdivision occurred in that subcontinent. In addition, the genetic diversity within South America was found to be larger than in Central and North America, suggesting that pumas from the latter subcontinent actually derive from a recent re-colonization event, following extinction in North America in the Late Pleistocene (ca. 10,000-12,000 years ago)

Mitochondrial DNA (mtDNA) markers have been extensively used in evolutionary studies of felids (e.g. Eizirik et al., 1998, 2001; Trigo et al., 2008). Although limited because they reveal only matrilineal history and contain a single realization of the stochastic processes of coalescence and lineage sorting (Avise, 1998), they are still powerful molecular tools to investigate recent phylogeographic patterns and demographic history. Given that felids tend to have male-biased gene flow (Pusey and Packer, 1987; Smith, 1993; Logan and Sweanor, 2001), mtDNA assessments of phylogeography are expected to provide more refined patterns of geographic structuring due to historical processes than nuclear markers. They may therefore be expected to be relevant benchmarks for maximum historical structuring, serving as baselines against which nuclear data sets may be compared. In addition, due to their four-fold lower effective population sizes $\left(\mathrm{N}_{\mathrm{e}}\right)$ relative to autosomal markers, mtDNA segments should be more sensitive to the effect of historical genetic drift. In combination with their relatively high substitution rates, these features render these markers potentially more sensitive to historical processes of population subdivision than equivalent segments of the nuclear genome.

Within the mtDNA, the NADH dehydrogenase subunit 5 (ND5) gene has been successfully used in phylogenetic and phylogeographic studies of felids and other carnivores (e.g. Culver et al., 2000; Trinca et al., 2012). In a previous study focusing on pumas (Culver et al., 2000), three mtDNA segments were employed (ND5, 16S and ATP8). Of these, ND5 showed the highest polymorphic content in this species, based on a segment spanning $318 \mathrm{bp}$. A new primer set for this gene was designed specifically for carnivores (Trigo et al., 2008), amplifying a longer fragment $(c a .750 \mathrm{bp}$ ) and exhibiting successful amplification across several families (e.g. Felidae, Mustelidae, Mephitidae, Procyonidae [unpublished data]).

In the present study we employ this longer ND5 segment to investigate the evolutionary history of $P$. concolor, with emphasis on South American populations, which were previously found to harbor high levels of diversity and inferred to have played a key role in the historical demography of this species (Culver et al., 2000). Given that the geographic sampling of South American pumas was limited in that first study, we aimed here to expand the representation of the various regions of this sub-continent, so as to allow refined inferences of population structure, maternal gene flow and demographic history. In addition to expanding the geographic coverage of South American regions to refine inferences on patterns of matrilineal subdivision, we have performed novel analyses on puma demographic history, which revealed consistent evidence of a recent population expansion in South America, prior to re-colonization of North America.

\section{Materials and Methods}

\section{Sample collection and laboratory procedures}

We obtained blood and tissue samples from 77 pumas including wild individuals captured during field-ecology projects, caught by farmers or road-killed, as well as captive animals with known geographic origin (Table S1). In addition, we also collected data from 109 additional individuals whose DNA was already available in the participant laboratories, some of which had been used in earlier genetic studies employing different markers (Culver et al., 2000; Castilho et al., 2011; Miotto et al., 2011, 2012). Therefore, as a whole we collected novel data from a total of 186 individuals. These samples were originated from a diverse array of geographic regions throughout most of the puma range, with greater emphasis on South America (see 
Table S1). Two samples of Puma yagouaroundi were also included to be used as outgroups in some analyses.

To select a marker that would provide suitable information levels, we initially examined the mtDNA fragments used in previous studies, especially those involving Neotropical felids (e.g. Eizirik et al., 1998, 2001; Johnson et al., 1998, 1999; Culver et al., 2000). We selected the ca. 750 bp-long fragment of the ND5 gene reported by Trigo et al. (2008), thus considerably increasing the information content derived from this marker relative to the previous phylogeographic study of the puma (Culver et al., 2000). Finally, the availability of ND5 sequences for the extinct felid Miracinonyx trumani (Barnett et al., 2005) was an additional asset of this segment, allowing the inclusion of this fossil taxon in some analyses.

In the case of new biological samples, DNA was extracted using either a standard phenol-chloroform approach (Sambrook et al., 1989) or a CTAB-based protocol (Doyle and Doyle, 1987). For all samples, a fragment of the ND5 gene was amplified by the Polymerase Chain Reaction (PCR) (Saiki et al., 1985) using the primers ND5-DF1 and ND5-DR1 (Trigo et al., 2008). PCR reactions were performed in a total volume of $20 \mu \mathrm{L}$ containing $2 \mu \mathrm{L}$ of empirically diluted DNA, $1 \mathrm{X}$ buffer, $1.5 \mathrm{mM} \mathrm{MgCl}_{2}, 0.2 \mu \mathrm{M}$ of each primer, $0.2 \mathrm{mM}$ dNTPs and $0.5 \mathrm{U}$ Platinum Taq DNA polymerase (Invitrogen), with a thermocycling profile as described by Tchaicka et al. (2007). PCR products were visualized on a $1 \%$ agarose gel stained with GelRed (Biotium), purified with the enzymes Exonuclease I and Shrimp Alkaline Phosphatase (Exo-SAP, GE Healthcare), sequenced in both directions using the DYEnamic ET Dye Terminator cycle sequencing kit (GE Healthcare) and read in a MegaBacE 1000 automated DNA sequencer.

Sequence electropherograms were visually inspected and edited using Chromas Lite 2.01 or FinchTV 1.4.0. Sequences were aligned with the CLUSTALW algorithm (Higgings et al., 1996) implemented in MEGA 4 (Tamura et al., 2007), followed by manual verification and editing. The resulting novel puma sequences were deposited in GenBank (accession numbers KF460496-KF460523).

\section{Data analysis}

Nucleotide and haplotype (gene) diversity indices were estimated with DnaSP 5.10 (Librado and Rozas, 2009) for the total sample, as well as for a sample set restricted to South America. In addition, we estimated diversity indices for geographic subsets identified in this study as distinct historical units (see below).

To investigate the evolutionary relationships among puma mtDNA lineages, haplotype networks were built using the median-joining approach (Bandelt et al., 1999), as implemented in the software Network 4.5.1.6. We explored two outgroup options for rooting the network, one with the $P$. yagouaroundi sequences generated here, and the other employing M. trumani sequences (Barnett et al., 2005).
We also performed an Analysis of Molecular Variance (AMOVA) (Excoffier et al., 1992) with Arlequin 3.5.1.2 (Excoffier and Lischer, 2010) to assess the differentiation among geographic populations, using samples from 174 individuals. Twelve samples were excluded (see Table S1) due to insufficient information on local provenance, i.e. cases where the original geographic information was absent (the case of some zoo animals) or too broad, such as a large country. This subset was also used in all other analyses that required precise geographic provenance, such as all AMOVAs, Mantel tests, spatial autocorrelation, regional neutrality tests, mismatch distribution and Bayesian skyline plots (see below for additional details).

AMOVAs were performed using $\Phi s t$ computed from a pairwise matrix based on $p$-distances. Statistical significance of $\Phi s t$ values was tested using 10,000 permutations. To minimize the effect of prior assumptions on puma geographic subdivision we tested a variety of different scenarios attempting to identify the best possible way to represent historical population structure in this species (i.e. the one that maximizes the estimated $\Phi s t$ ). These AMOVAs were based on two sample sets: (1) South America (SA) only: and (2) the full sample of SA, Central America (CA) and North America (NA).

Within sample set 1 , we assessed the following scenarios: 1a) the four SA subspecies suggested by Culver et al. (2000); 1b) grouping samples according to their biomes of origin (adapted from IBGE (2010) and Olson et al. (2001)) while sequentially joining adjacent populations that exhibited non-significant $\Phi_{s t}$ values; 1c) a sequential approach in which samples were initially grouped by immediate geographic proximity, then merged with other groups when they exhibited non-significant $\mathrm{p}$-values for their pairwise $\Phi s t$, and subsequently joined to additional contiguous populations with which the $\Phi s t$ estimate was low. For strategies $1 \mathrm{~b}$ and $1 \mathrm{c}$, the overall $\Phi s t$ value was monitored at every sequential step and the successive grouping strategy was maintained until a peak was observed. In this process, when we observed non-significant p-values between population groups, we still tested the effect of changing individuals from one adjacent unit to the other, so as to fine-tune the estimate that maximized the overall $\Phi s t$ value for this sample set.

In the second round of AMOVAs, based on sample set 2 (full sample), we employed the following strategies: 2a) the six subspecies suggested by Culver et al. (2000); 2b) incorporating the best grouping for SA identified in strategy $1 \mathrm{c}$ and adding the CA and NA samples as additional populations; $2 \mathrm{c}$ ) testing the overall division into three subcontinents, including an additional adjustment separating Central America into two subgroups (northern and southern); 2d) a two-level hierarchical analysis considering subcontinents (best scenario found in $2 \mathrm{c}$ ) as broader groups, within which we placed the regional populations identified with strategy $1 \mathrm{c}$. 
A third round of AMOVAs was performed to test the hypotheses raised by Culver et al. (2000), who postulated that major South American rivers could act as historical barriers to gene flow in this species. This was performed separately for the Amazon and Paraná rivers, by considering populations on either side of each river as distinct geographic units. Only populations located near the respective river were considered here. Given the available sampling on both sides of each river, we established an arbitrary cutoff of $\leq 610 \mathrm{~km}$ on each side of the Paraná, and $\leq 1340 \mathrm{~km}$ for the Amazon, so as to include a reasonable number of individuals and localities in both assessments.

Additionally, to investigate spatial patterns of genetic structure in pumas we assessed the correlation between genetic and geographic distances for all pairs of sampled individuals using a Mantel test (Mantel, 1967). This was performed with the program Alleles in Space (AIS) (Miller, 2005), employing the proportion of differences (i.e. a p-distance equivalent) to generate the genetic distance matrix and 10,000 permutations to assess statistical significance. We also employed AIS to perform a spatial autocorrelation analysis of the data set, using 11 distance classes, equalized sample sizes across classes, and 10,000 permutations to assess significance.

Finally, we conducted a set of analyses to investigate the demographic history of pumas. We performed neutrality tests (Tajima's D, Fu \& Li' D* and F*, Fu's Fs) with DnaSP, as well as a mismatch distribution analysis (Rogers and Harpending, 1992; Schneider and Excoffier, 1999) with Arlequin. In addition, we used the program Beast 1.6.1 (Drummond and Rambaut, 2007) to perform estimates of coalescence times and past demography. We defined the best model of nucleotide substitution for our data set, which was the HKY (Hasegawa et al., 1985) + G model, using the Akaike Information Criterion (AIC, Akaike, 1974) implemented in jModelTest 0.1 (Posada, 2008). Our first set of Beast runs was aimed at estimating the molecular clock rate for our segment in puma lineages. We assumed a Yule Process for the tree prior and incorporated an uncorrelated lognormal relaxed molecular clock. In order to better fit the expectations of the Yule process we only included five divergent puma haplotypes, along with the two jaguarundi sequences generated here. To calibrate the molecular clock we assumed that pumas and jaguarundis diverged between 3.16 and 6.01 MYA (95\% HPD of the estimate reported by Johnson et al. (2006) using a nuclear supermatrix). We applied a uniform prior using these ages as conservative minimum and maximum boundaries, respectively. The final run was based on $10^{8} \mathrm{MCMC}$ generations, with samples taken every $10^{4}$ steps, and the first $10^{4}$ steps removed as burn-in.

The second set of Beast analyses aimed to infer the time of the most recent common ancestor $\left(t_{M R C A}\right)$ of different groups of samples, as well as to reconstruct the demographic history of pumas by estimating past fluctuations in population size via the Bayesian Skyline Plot (BSP) ap- proach (Drummond et al., 2005). We assumed a Bayesian skyline tree prior and a strict molecular clock, whose evolutionary rate was based on the estimate derived from the first round of analyses. We assessed the $t_{M R C A}$ for four different sample sets: (i) complete sample; (ii) South America only; (iii) North and Central Americas (NA+NCA); and (iv) a subset of $24 \mathrm{NA}+\mathrm{NCA}$ samples that formed a regionally endemic subclade in the haplotype network, suggestive of autochthonous diversification (see Results). The BSP analyses were performed only for sets (i) and (ii), as their larger sample size allowed for more robust demographic inferences. The MCMC parameters were the same as in the first set of Beast analyses.

\section{Results}

After removal of incorporated primer sequences and low-quality fragment edges, double-stranded sequences for a 669-bp segment of the mtDNA ND5 gene were obtained for 156 puma individuals sampled in South America, 17 from Central America, and 13 from North America (Table S1, Figure 1). Additional sequences of the same fragment were obtained for two $P$. yagouaroundi individuals.

The puma data set contained 33 variable sites (32 transitions and one transversion), 25 of which were phylogenetically informative (Table 1). Overall, there were 28 haplotypes, 22 of which occurred in South America

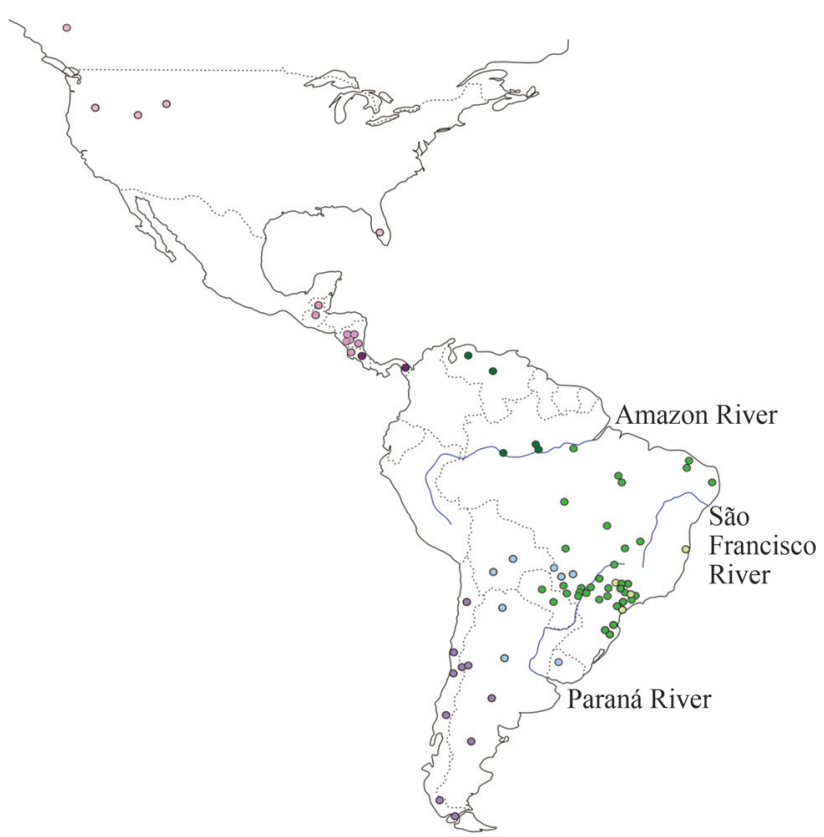

Figure 1 - Geographic distribution of the Puma concolor samples analyzed here. Blue lines indicate three major rivers. The different colors indicate the seven groups identified with the AMOVA (see text and Table 3 for details): Northern Central America + North America (NCA+NA, in light pink), Southern Central America (SCA, in dark pink), Northern South America (NSA, in dark green), Central-North-Eastern South America (CNESA, in medium green), Eastern South America (ESA, in light green), Central-Southern South America (CSSA, in light blue) and Southwestern South America (SWSA, in purple). 


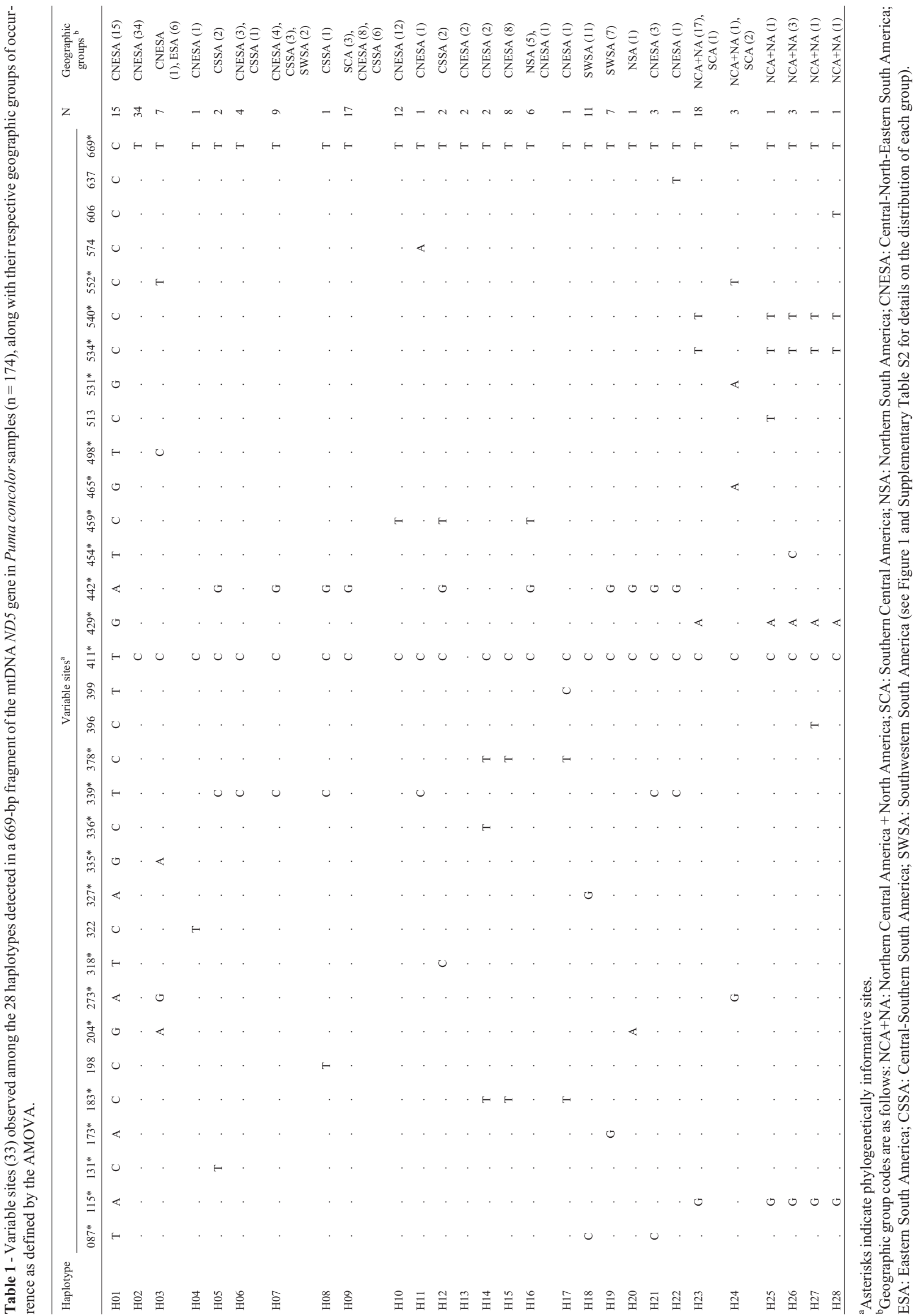


(H01-H22), one of them (H09) being shared with Central America (Figure 2A). Moderate to high levels of haplotype diversity were observed, while nucleotide diversity was rather low (Table 2).

Evolutionary relationships among haplotypes were inferred using the median-joining network approach (Figure $2 \mathrm{~A}$ ), which showed a clear separation between lineages from South America (H01-H08, H10-H22) and those from North America and most of the haplotypes from Central America (H23-H28). The main exception was a haplotype (H09) found in southern Central America (Costa Rica), which is also common in central South America and is equidistant (five mutational steps) from the two closest haplotypes found in Central and North America (H23 and H24).

Among the 22 South American haplotypes, two (H16 and H20) were found north of the Amazon River (Brazil and Venezuela), with $\mathrm{H} 16$ also being sampled in one individual from southern Brazil. We observed very high levels of genetic diversity in central South America (including Bolivia, Paraguay, Uruguay, northern Argentina and the central-western, southeastern and southern regions of Brazil), where 15 distinct haplotypes were sampled (H01-H12, H14, H15 and H21). Among these, some haplotypes exhibited a localized distribution, such as H05, H08 and H12, which were found only in the Pantanal biome. A peculiar
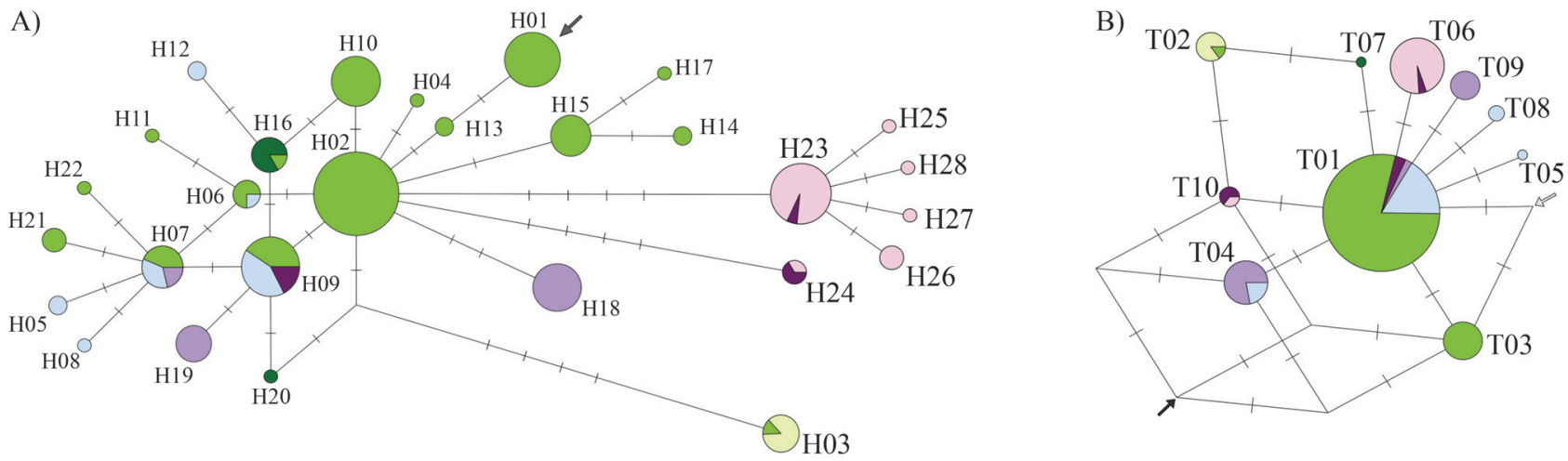

Figure 2 - Median-joining networks based on puma ND5 haplotypes. The area of each circle is proportional to the haplotype frequency. The relative frequency of populations in each haplotype is indicated by the proportion of different colors (coded as in Figure 1). A) Analysis of the full data set (669 bp). The arrow indicates the point where the outgroup $P$. yagouaroundi is connected. B) Analysis of a subset of the nucleotide sites that overlap with the Miracinonyx trumani sequence (286 bp). Arrows indicate the points where the outgroup taxa join the network: P. yagouaroundi (in gray; 32 mutational steps from the connection point), and M. trumani (in black; 19 steps from the connection point).

Table 2 - Nucleotide and gene diversity levels observed in Puma concolor ND5 sequences. Geographic groups were defined on the basis of the AMOVA results (see text and Tables 1 and 3).

\begin{tabular}{lclll}
\hline Sub-Continent & $\mathrm{N}^{\mathrm{b}}$ & Nucleotide Diversity $( \pm \mathrm{SE})$ per site & Gene diversity $( \pm \mathrm{SE})$ & Haplotypes \\
\hline North America & 13 & $0.00217(0.00158)$ & $0.295(0.156)$ & $\mathrm{H} 23-\mathrm{H} 25$ \\
Central America & 17 & $0.00523(0.00114)$ & $0.794(0.075)$ & $\mathrm{H} 09, \mathrm{H} 23, \mathrm{H} 24, \mathrm{H} 26-\mathrm{H} 28$ \\
South America & 156 & $0.00428(0.00027)$ & $0.904(0011)$ & $\mathrm{H} 01-\mathrm{H} 22$ \\
Total & 186 & $0.00547(0.00029)$ & $0.920(0.008)$ & \\
\hline Geographic region $^{\mathrm{a}}$ & & & & \\
\hline NA+NCA & 24 & $0.00179(0.00094)$ & $0.496(0.119)$ & $\mathrm{H} 23-\mathrm{H} 28$ \\
SCA & 6 & $0.00608(0.00155)$ & $0.733(0.155)$ & $\mathrm{H} 09, \mathrm{H} 23, \mathrm{H} 24$ \\
NSA & 6 & $0.00104(0.00067)$ & $0.333(0.215)$ & $\mathrm{H} 16, \mathrm{H} 20$ \\
CNESA & 97 & $0.00315(0.00027)$ & $0.828(0.027)$ & $\mathrm{H} 01-\mathrm{H} 04, \mathrm{H} 06, \mathrm{H} 07, \mathrm{H} 09-\mathrm{H} 11, \mathrm{H} 13-\mathrm{H} 17$, \\
& 6 & $0.00000(0.00000)$ & $0.000(0.000)$ & $\mathrm{H} 21, \mathrm{H} 22$ \\
ESA & 15 & $0.00246(0.00047)$ & $0.810(0.078)$ & $\mathrm{H} 05-\mathrm{H} 09, \mathrm{H} 12$ \\
CSSA & 20 & $0.00334(0.00032)$ & $0.595(0.073)$ & $\mathrm{H} 07, \mathrm{H} 18, \mathrm{H} 19$ \\
SWSA & 174 & $0.00553(0.00030)$ & $0.919(0.010)$ & \\
Total & & &
\end{tabular}

${ }^{\mathrm{a}}$ Geographic acronyms are as in Table 1.

${ }^{b} \mathrm{~N}=$ number of individuals sampled for each continent/region. All samples $(\mathrm{n}=186)$ were used for the sub-continental analysis, while 12 individuals lacking detailed geographic information were excluded from the regional analysis, resulting in a sample of 174 animals. 
case was that of haplotype H03, sampled east and southeast of the São Francisco River (see Figure 1), and also in one individual from the Brazilian central-western region. This haplotype is five mutational steps away from its closest relatives, a distance which is equal to or larger than that observed between South American lineages and most of those sampled in North and Central America (4 mutational steps: H23 and H24; 5 mutational steps: H25, H26, H27 and $\mathrm{H} 28$ ). Individuals sampled along the Andes harbored two different haplotypes (H18 and H19), with $\mathrm{H} 18$ being more broadly distributed across the central and southern Cordillera, all the way to its extreme south in Patagonia.

In contrast, a single main haplotype (H23) was sampled in all surveyed countries from North and Central Americas (see Figure 2A). Four other haplotypes were connected to this common sequence by a single mutational step each, leading to a star-like appearance of this portion of the network. Among these haplotypes related to H23, H25 was found in the Florida peninsula (USA), H27 in Nicaragua, $\mathrm{H} 28$ in Guatemala, and H26 was sampled in both of the latter countries. Another haplotype (H24) found in Central and North America (Panama, Costa Rica and Florida peninsula [USA]) was quite distinct, differing by 8 mutational steps from $\mathrm{H} 23$, and by 4 steps from its closest relative, the common South American haplotype H02.

When the $P$. yagouaroundi sequences were used as outgroups in the network (Figure 2A) they were connected by 85 mutational steps to puma haplotype H01, supporting this position for the puma mtDNA root. Haplotype H01 is found in central South America (Paraguay, as well as the Brazilian states MS, SP and MG), differing by at least six mutational steps from the main North and Central American haplotypes. When the M. trumani sequence was included in the network (Figure 2B), the sequence alignment length was reduced to $286 \mathrm{bp}$ to match the segment available for this outgroup. Due to this reduction in the number of sites, the network became less resolved, but the results still suggested that the outgroup was connected more closely to South American and southern Central American pumas than to northern Central and North American haplotypes.

To investigate the population genetic structure in more quantitative detail we performed several rounds of AMOVA, employing different geographic clustering strategies. In the first stage, when only South American pumas were analyzed, $\Phi s t$ values were quite high and statistically significant, with strategy $1 \mathrm{c}$ yielding the highest overall $\Phi s t$ (Table 3). In the second round of AMOVA, using the full sample set, we found even higher $\Phi s t$ values. The highest overall value was obtained with strategy $2 \mathrm{~d}$, employing a two-level AMOVA (Table 3). Central America was best represented as two distinct groups, northern and southern, with the former being merged with North America. In the best two-level scenario (see Table 3 ), we also noted that the $\Phi s c$ and $\Phi c t$ were $0.41904(\mathrm{p}=0.000 \pm 0.000)$ and 0.43693
Table 3 - Best $\Phi s t$ values for different population structure scenarios in Puma concolor, as assessed with an AMOVA approach.

\begin{tabular}{|c|c|}
\hline Group & Фst \\
\hline \multicolumn{2}{|l|}{ 1. South America only (144 individuals) } \\
\hline a) 4 SA subspecies proposed by Culver et al. (2000) & $0.22001 *$ \\
\hline b) Grouped biomes from $\mathrm{SA}^{\mathrm{a}}$ & $0.25871^{*}$ \\
\hline $\begin{array}{l}\text { c) Five groups from SA (NSA, CNESA, ESA, CSSA and } \\
\text { CWSA) }\end{array}$ & $0.35993 *$ \\
\hline \multicolumn{2}{|l|}{ 2. Total sample (174 individuals) } \\
\hline a) 6 subspecies proposed by Culver et al. (2000) & $0.42353 *$ \\
\hline $\begin{array}{l}\text { b) } 7 \text { groups }[(\mathrm{NA}+\mathrm{NCA}), \mathrm{SCA}, \mathrm{NSA}, \mathrm{CNESA}, \mathrm{ESA} \text {, } \\
\text { CSSA and CWSA }]^{\mathrm{b}}\end{array}$ & $0.57314 *$ \\
\hline c) $\mathrm{NA}+\mathrm{NCA} \times \mathrm{SCA} \times \mathrm{SA}$ subcontinents ${ }^{\mathrm{c}}$ & $0.55740^{*}$ \\
\hline $\begin{array}{l}\text { d) 2-level [(NA+NCA) x SCA x (NSA + CNESA + ESA } \\
+\mathrm{CSSA}+\mathrm{CWSA})]^{\mathrm{d}}\end{array}$ & $0.67290^{*}$ \\
\hline \multicolumn{2}{|l|}{ 3. Barriers } \\
\hline Amazon River acting as a barrier ${ }^{\mathrm{e}}$ & $0.34739 *$ \\
\hline Paraná River acting as a barrier ${ }^{\mathrm{e}}$ & $0.09041^{*}$ \\
\hline
\end{tabular}

* Significant Sst $(\mathrm{p}<0.01)$.

3 groups: $1^{\text {st }}$-northern Amazon Rainforest (Tropical Moist Broadleaf Forests), Tropical Dry Broadleaf Forests and Tropical Grasslands, Savannas and Shrublands in Venezuela; $2^{\text {nd }}$-southern Amazon Rainforest and Atlantic Forests (Tropical and Subtropical Moist Broadleaf Forests), Pantanal (Flooded Grasslands and Shrublands), Caatinga (Xeric Shrublands), Cerrado, Pampas, Gran Chaco and Beni Savanna (Tropical and Subtropical Grasslands, Savannas and Shrublands), Patagonian Pampas (Temperate Grasslands, Savannas and Shrublands) and Tropical Dry Broadleaf Forests in Bolivia; $3^{\text {rd }}$-Andean biomes: Temperate Broadleaf and Mixed Forests, Montane Grasslands and Shrublands, Desert and Xeric Shrublands and Mediterranean Forests, Woodlands and Scrubs (Olson et al., 2001; IBGE 2010).

${ }^{\mathrm{b}}$ Acronyms for geographic groups are as defined in Table 1 and Figure 1.

${ }^{\mathrm{c}}$ Central America was divided into two separate groups, northern (NCA) and southern (SCA).

${ }^{\mathrm{d}} 1{ }^{\text {st }}$ level: 3 groups: NA+NCA (2 populations), SCA (1 population), SA ( 5 populations); $2^{\text {nd }}$ level: 7 populations $([\mathrm{NA}+\mathrm{NCA}] \times[\mathrm{SCA}] \times[\mathrm{NSA}+$ CNESA + ESA + CSSA + CWSA]);

${ }^{\mathrm{e}}$ Considering only samples collected near the river (see text for details).

$(\mathrm{p}=0.01871+-0.00135)$, respectively. Pairwise estimates of $\Phi$ st were carried out at the various spatial scales tested in these scenarios, and helped assess the distinctiveness of large-scale as well as regional population units (Tables S4 and S5).

Finally, we performed a third round of AMOVA to test two large rivers as possible barriers to historical gene flow in this species. We observed high $\Phi s t$ values when the Amazon River was assessed (see Table 3). The $\Phi$ st value found for the Parana River was rather low (0.09), although still statistically significant.

Mantel Tests (Figure S1) revealed a significant correlation between genetic and geographic distances for the total geographic sample $(r=0.48 ; p<0.001)$, indicating that isolation by distance plays a relevant role in the genetic structuring of this species. As for the analysis of South American samples alone, the resulting value was 0.085 
$(\mathrm{p}=0.09347)$, which suggests that within this subcontinent there is no significant influence of isolation by distance.

The spatial autocorrelation analysis (performed only for the full data set) yielded results that were consistent with those of the Mantel test. There was a trend for an increase in the statistic Ay (representing the average pairwise genetic distance within geographic distance class ' $y$ ') as the geographic distance increased, and the overall relationship was statistically significant ( $p=0.0048)$, supporting the inference that isolation by distance affected the patterns observed in our global data set.

Another front of analyses pertained to demographic history assessments. When we conducted a Mismatch Distribution analysis, the results indicated a unimodal pattern for both data sets (full sample and South American samples only) (Figure 3) compatible with a scenario of recent demographic expansion. In addition, the neutrality tests yielded negative values for all indices, with those of Fu's Fs being significantly negative with respect to neutral expectations for both data sets (Table 4).

The Bayesian analyses performed with Beast further helped shed light onto the historical demography pumas as revealed by the mtDNA. In the first round of analyses, using five individuals with the most divergent haplotypes and
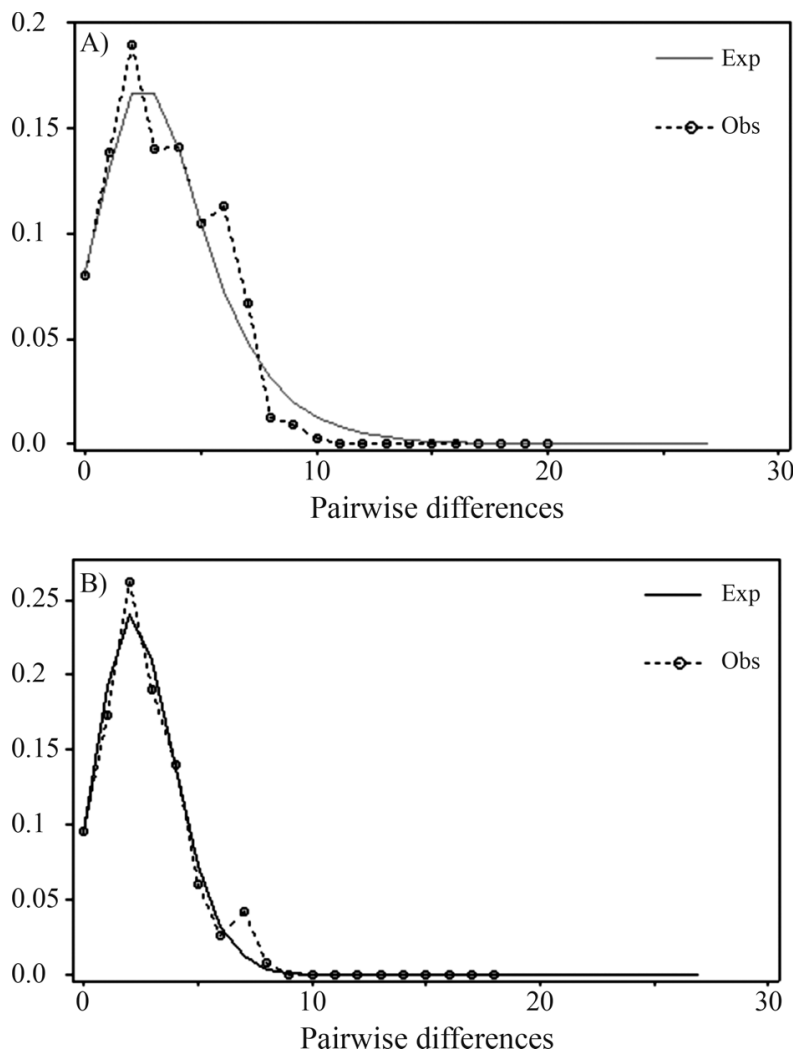

Figure 3 - Graphs depicting the results of the Mismatch Distribution analysis for the total sample (A) and South American samples alone (B). The analysis was performed with 669 bp of $P$. concolor ND5 sequences (excluding all sites with missing information or gaps). The dashed line represents the observed pattern, while the continuous line depicts the pattern expected under a model of sudden demographic expansion.
Table 4 - Neutrality tests for Puma concolor ND5 sequences, considering both the 'Total' and 'South American' (SA) sample sets.

\begin{tabular}{lcc}
\hline & Total & SA \\
\hline Tajima's D & -1.16291 & -0.98375 \\
Fu and Li's D* & -0.82174 & -0.39340 \\
Fu and Li's F* & -1.15989 & -0.75225 \\
Fu's Fs & $-9.322^{\mathrm{a}}$ & $-7.283^{\mathrm{a}}$ \\
\hline
\end{tabular}

${ }^{\mathrm{a}}$ Significant values $(\mathrm{p}<0.02)$.

two jaguarundis, we estimated the substitution rate of the analyzed ND5 segment to be $2.054 \%$ per million years (MY). Applying this substitution rate in the second set of analyses, we inferred the mean $t_{M R C A}$ of pumas to be 0.237 MYA (95\% HPD: 0.105-0.391 MYA). For South American pumas, the mean $t_{M R C A}$ was estimated to be 0.211 (0.091-0.353) MYA. When North American (NA) and Central American (CA) samples were analyzed separately, their mean estimated $t_{M R C A}$ was $0.231(0.102-0.387)$ MYA. Finally, we estimated the $t_{M R C A}$ for a subset of $24 \mathrm{NA}+\mathrm{CA}$ samples that formed an endemic monophyletic cluster (see Figure 2A), yielding a value of 0.037 (0.006-0.077) MYA.

The Bayesian skyline plot analysis revealed evidence of a very recent (ca. 8,000 years ago) demographic expansion in pumas (Figure 4). The signal for this expansion was apparent with both data sets (full sample and South American pumas only), with only minor differences in the estimated parameters.

\section{Discussion}

\section{mtDNA diversity and genealogical history}

The mtDNA data set analyzed in this study allowed a deeper understanding of the matrilineal history of pumas, refining, extending and in some cases adjusting the inferences previously put forth by Culver et al. (2000). Our initial observation was that ND5 is indeed a very informative coding mtDNA segment for phylogeographic studies of felids, and that the longer segment employed here (relative to the one reported by Culver et al., 2000) does provide useful additional information regarding this species' diversity and evolutionary history. For example, the ND5 data set used here contained 33 variable sites and allowed the identification of 28 different puma haplotypes, while the full data set employed by Culver et al. (2000), including ND5, ATP8 and 16S segments, contained 15 variable sites and defined 14 different haplotypes.

Pumas exhibited moderately high levels of diversity, which could be directly compared to only two other felid species that have so far been sequenced for the same mtDNA segment and whose sequences for available for assessment (Trigo et al., 2008). Both of these Neotropical cats, Leopardus tigrinus and L. geoffroyi, were sequenced for a slightly shorter fragment, so we adjusted our alignment to include only the matching $567 \mathrm{bp}$ and thus allow an 

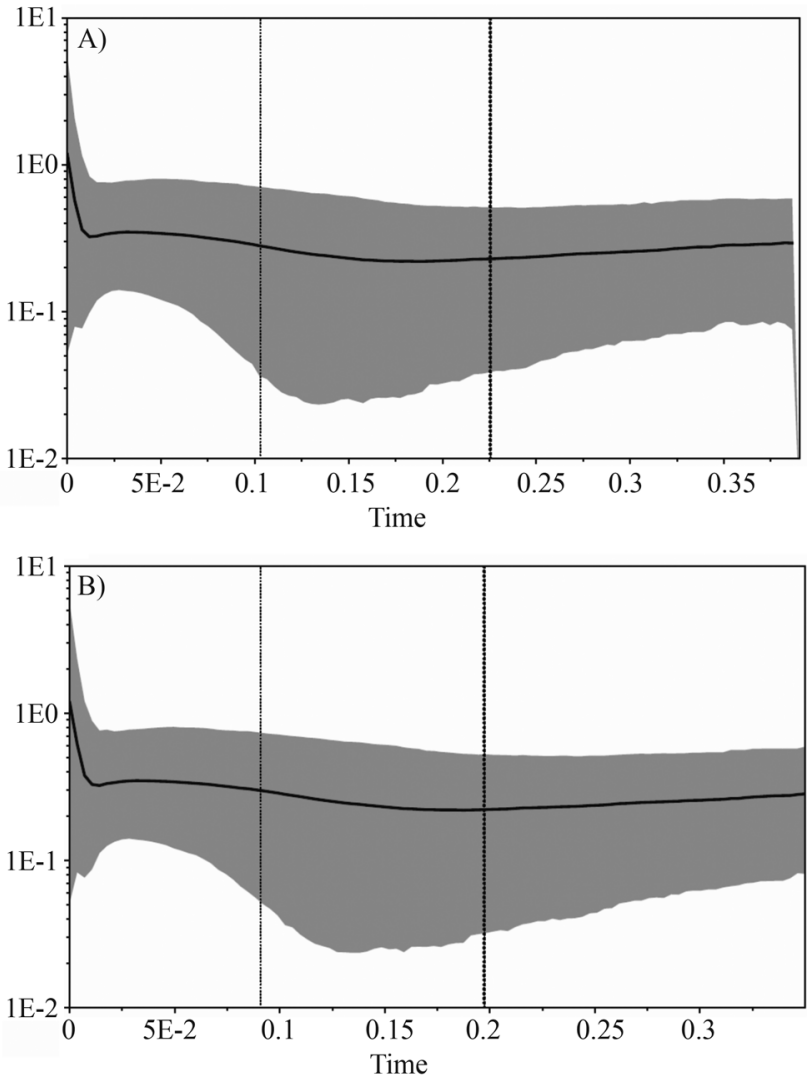

Figure 4 - Bayesian Skyline plots derived from an alignment of puma ND5 sequences. In (A) the analysis was run for all puma samples, and in (B) for South American pumas only. The thick solid line represents the mean, while the $95 \%$ HPD (highest posterior density) limits are shown by the blue areas. The vertical dashed lines refer to the $t_{M R C A}$, with the thin line indicating the lower 95\% HPD limit, and the thick line representing the mean. The $\mathrm{x}$-axis is depicted on a scale of millions of years (myr). The $y$-axis represents the effective population size $\left(\mathrm{N}_{\mathrm{e}}\right)$ multiplied by the generation time (also in myr). Assuming a generation time of 5 years, the numbers on this axis should be multiplied by 200,000 to yield interpretable values.

exact comparison (Table S3). This assessment revealed that pumas possess higher gene diversity than either of these other species, as well as slightly higher nucleotide diversity. Indeed, the observed levels of haplotype (gene) diversity in pumas were quite high, while nucleotide diversity was more modest, suggestive of rather recent mtDNA coalescence in this species.

When subcontinental or regional groups of pumas were compared, we observed that haplotype and nucleotide diversity indices were consistently higher for South and Central America, relative to those estimated for North America (Table 2). Gene diversity was highest for South America, while nucleotide diversity reached a maximum in Central America. North American pumas presented low values for both indices, which were at least two-fold lower than those of the other sub-continental groups. When the South American regional groups defined by the AMOVA (see Figure 1 and Table 3 for their definition) were assessed, we observed that the CNESA and CSSA groups ex- hibited the highest haplotype diversity, with the SWSA and NSA groups also presenting high values (Table 2).

The high gene diversity estimated for pumas could be examined in more detail with the use of haplotype networks (Figure 2A), which depicted intricate relationships among sequences, especially in South America. Such a pattern is indicative of a complex evolutionary history, with some suggestion of geographic structuring but no clear-cut separation of well-defined clades. Some portions of the network are suggestive of a recent population expansion involving South American lineages, with central haplotypes giving rise to multiple derived sequences differing by a single mutational step each. Central America was also observed to bear a complex mixture of haplotypic lineages, with more than one connection to basal South American sequences and evidence of internal structure (see Figure 2A and Table $3)$. In contrast, the lineages sampled in North America exhibited a much simpler pattern, dominated by a common haplotype (H23) shared with Central America, from which four other lineages have recently evolved. This shape is indicative of a recent population expansion involving these haplotypes, whose sampling locales indicate a present distribution across North America and also in Central America, especially in the northern portion of the latter (Figures 1 and 2).

In North America, an unusual pattern was observed in an individual from Florida (USA) that carried haplotype H24, which is shared with animals from southern Central America (Panama and Costa Rica) and is genetically distant from the other lineages found throughout North America. Given the record of human-induced introgression of puma mtDNA lineages from Central America to Florida in the 1960s (O'Brien et al., 1990), it is possible that this individual descends from a female translocated during that period, implying that such haplotype sharing may be a human-induced artifact. If this were indeed the case, our results would in fact be an underestimate of the differentiation between SCA and NA+NCA, since haplotype H24 may only naturally occur in the former.

Central America and northern South America (NSA) did not share haplotypes, implying no evidence of historical matrilineal gene flow between these regions. Possible barriers include the northernmost Andean Cordillera or the Darien Straits in Panama, as suggested for jaguars by Eizirik et al. (2001) (but see Ruiz-Garcia et al., 2013 for a different view). Detailed sampling in that region would be required to distinguish between these two hypotheses. Although no haplotype was shared between Central America and northern South America, we did observe a shared haplotype (H09) between southern Central America (Costa Rica) and the central region of South America. This suggests some continued matrilineal connectivity between these areas (necessarily going through northern South America), or the retention of an ancestral polymorphism that predates the implicated phylogeographic subdivision. 
Since the available sampling for northern South America is still modest (see Figure 1), both hypotheses remain viable and should be the focus of additional scrutiny. Moreover, northwestern South America has been reported to harbor high levels of genetic diversity and a complex evolutionary history for several mammalian taxa (e.g. Eizirik et al., 1998; Ruiz-García et al., 2009, 2010, 2012; Thoisy et al., 2010), highlighting the need to further investigate pumas from this portion of their range to assess their role in the overall phylogeographic structure of the species.

The network root based on the outgroup Puma yagouaroundi indicates that the most ancestral lineage of current pumas is located primarily in central South America. When we considered M. trumani as the outgroup, once again the rooting was placed primarily in South America, reasserting the area of occurrence of the earliest ancestor of the current lineages and helping reveal the direction of evolution of pumas throughout their distribution.

\section{Population structure}

The AMOVA results revealed extremely high $\Phi_{s t}$ values in many of the assessed scenarios (see Table 3 ). The highest $\Phi$ st value, used to define the scenario that best explains the current partitioning of mtDNA diversity, was found when a 2-level AMOVA was conducted. The first level separated "subcontinents" as major units (NA+NCA, SCA and SA), while the second level identified subdivisions within the "subcontinents". Several analyses, following the steps outlined in the AMOVA strategy $2 \mathrm{~b}$ (data not shown), demonstrated that other possible groupings were almost as good, indicating that there is no clear-cut definition of the structure in central South America, but demonstrating that this region is a genetic hotspot for this species, with considerable structure but complex historical relationships.

Our next step was to assess the role of major rivers as historical barriers to female gene flow. Our sampling allowed a test of two riverine barriers proposed by Culver et al. (2000), which postulated that the Amazon and Paraná rivers might have induced the differentiation of historical population units. Our results supported an important role for the Amazon River, corroborating the hypothesis previously raised for pumas (Culver et al., 2000), and showing a pattern consistent with inferences made for other Neotropical felids such as Leopardus pardalis, L. wiedii and Panthera onca (Eizirik et al., 1998, 2001). On the other hand, the influence of the Paraná River appears to be much lower than previously hypothesized, although we still observed significant $\Phi s t$ values when we compared populations separated by this watercourse. Although they were significant, the magnitude of the differentiation was considerably lower than that estimated for the Amazon River (see Table 3), and several AMOVA assessments comparing regional populations on the same side of the Paraná River yielded higher $\Phi s t$ values than those obtained in the com- parison between the two sides. These findings suggest that, although this river may play a role in limiting regional maternal gene flow in pumas, it does not induce major differentiation between clear-cut historical units. Such an observation has implications for the definition and delimitation of puma subspecies, two of which (P. c. cabrerae and $P$. c. capricornensis) have been suggested to be separated by this river (Culver et al., 2000).

\section{Demographic history}

The $t_{M R C A}$ estimates derived from both data sets were very similar, indicating that the age of the common ancestor for all samples was essentially the same as that for the South American subset. Taken together with the other results (e.g. network, diversity indices), this finding supports the inference that most of the extant diversity of the puma mtDNA resides in South America, and that the deepest history of coalescence of its lineages is fully represented in this subcontinent.

The signal of demographic expansion on both subcontinents suggests that this process seems to have occurred simultaneously, after the last glacial maximum. This inference is consistent with the hypothesis raised by Culver et al. (2000), of an extinction of North American pumas in the late Pleistocene, followed by re-colonization from South America. Our results corroborate and extend this hypothesis, showing evidence for a substantial and very recent demographic expansion in South America, which likely preceded or included the re-colonization of North America. Such a pattern was not clearly observed in previous studies and sheds light onto the historical demography of present-day puma lineages. Our findings indicate that pumas were substantially affected by faunal changes induced by the Late Pleistocene extinction of large mammals, likely disappearing from North America, as previously postulated, with subsequent recolonization from the south. What is new in our results is the inference of a substantial demographic expansion in South America ca. 8,000 years ago, possibly induced by release from competitive interactions with other large carnivores that went extinct during the Late Pleistocene event. We see no evidence of a secondary expansion in North America, as the full data set mirrors the results observed with South America alone. We thus conclude that pumas likely re-colonized North America spurred by this Holocene demographic expansion stemming from South America. If corroborated by additional genetic markers and more refined sampling, especially in northern South America, this hypothesis would provide a useful demographic framework for pumas against which local patterns of genetic structure, genomic variation and population connectivity can be assessed.

\section{Acknowledgments}

We thank C.R. Sarturi, A. Schnorr, A.C.G. Escobar, C.B. Pires, A.T. Hahn, F. Britto, F.G. Grazziotin, T. Haag, 
T.C. Trigo and T.L.L. Simão for laboratory assistance and helpful discussions regarding data analysis and interpretation, as well as J. Schiefelbain and M. G. da Silva for additional support. This work was funded by Conselho Nacional de Desenvolvimento Científico e Tecnológico (CNPq), Brazil, and Companhia Energética de São Paulo (CESP), Brazil. Part of this research was also supported by funds from the Intramural Research Program of the National Institutes of Health, National Cancer Institute, USA awarded to WEJ and SJO.

\section{References}

Akaike H (1974) A new look at the statistical model identification. IEEE Trans Autom Contr 19:716-723.

Avise JC (1998) The history and purview of phylogeography: A personal reflection. Mol Ecol 7:371-379.

Bandelt HJ, Forster P and Röhl A (1999) Median-Joining networks for inferring intraspecific phylogenies. Mol Biol Evol 16:37-48.

Barnett R, Barnes I, Phillips MJ, Martin LD, Harington CR, Leonard JA and Cooper A (2005) Evolution of the extinct Sabretooths and the American cheetah-like cat. Curr Biol 15:R589-R590.

Beier P, Vaughan MR, Conroy MJ and Quigley H (2003) A review of literature related to the Florida panther. Bureau of Wildlife Diversity Conservation - Florida Fish and Wildlife Conservation Commission, Tallahassee, 203 pp.

Castilho CS, Marins-Sá LG, Benedet RC and Freitas TO (2011) Landscape genetics of mountain lions (Puma concolor) in southern Brazil. Mammal Biol 76:476-483.

Culver M, Johnson WE, Pecon-Slattery J and O'Brien SJ (2000) Genomic ancestry of the American Puma (Puma concolor). J Hered 91:186-197.

Doyle JJ and Doyle JL (1987) A rapid DNA isolation procedure for small quantities of fresh leaf tissue. Phytochem Bull 19:11-15

Drummond AJ and Rambaut A (2007) BEAST: Bayesian evolutionary analysis by sampling trees. BMC Evol Biol 7:e214.

Drummond AJ, Rambaut A, Shapiro B and Pybus OG (2005) Bayesian coalescent inference of past population dynamics from molecular sequences. Mol Biol Evol 22:1185-1192.

Eizirik E (2012) A molecular view on the evolutionary history and biogeography of Neotropical carnivores (Mammalia, Carnivora). In: Patterson BD and Costa LP (eds) Bones, Clones, and Biomes: An Extended History of Recent Neotropical Mammals. University of Chicago Press, Chicago, pp 123-142.

Eizirik E, Bonatto SL, Johnson WE, Crawshaw Jr PG, Vie JC, Brousset DM, O'Brien SJ and Salzano FM (1998) Phylogeographic patterns and evolution of the mitochondrial DNA control region in two Neotropical cats (Mammalia, Felidae). J Mol Evol 47:613-624.

Eizirik E, Kim J-H, Menotti-Raymond MA, Crawshaw Jr PG, O'Brien SJ and Johnson WE (2001) Phylogeography population history and conservation genetics of jaguars (Panthera onca, Mammalia, Felidae). Mol Ecol 10:65-79.

Excoffier L and Lischer H (2010) Arlequin suite ver. 3.5: A new series of programs to perform population genetics analyses under Linux and Windows. Mol Ecol Resourc 10:564-567.
Excoffier L, Smouse PE and Quattro JM (1992) Analysis of molecular variance inferred from metric distances among DNA haplotypes: Application to human mitochondrial DNA restriction data. Genetics 131:479-491.

Hasegawa M, Kishino H and Yano T (1985) Dating of human-ape splitting by a molecular clock of mitochondrial DNA. J Mol Evol 22:160-174.

Higgings DG, Thompson JD and Gibson TJ (1996) Using CLUSTAL for multiple sequence alignments. Meth Enzymol 266:383-402.

Johnson WE, Culver M, Iriarte JA, Eizirik E, Seymour KL and O'Brien SJ (1998) Tracking the evolution of the elusive Andean mountain cat (Oreailurus jacobita) from mitochondrial DNA. J Hered 89:227-232.

Johnson WE, Pecon-Slattery J, Eizirik E, Kim JH, MenottiRaymond M, Bonacic C, Cambre R, Crawshaw P, Nunes A, O'Brien SJ, et al. (1999) Disparate phylogeography patterns of molecular genetic variation in four closely related South American small cat species. Mol Ecol 8:S79-S92.

Johnson WE, Eizirik E, Pecon-Slattery J, Murphy WJ, Antunes A, Teeling E and O'Brien SJ (2006) The late Miocene radiation of modern Felidae: A genetic assessment. Science 311:7377.

Kurtén B and Anderson E (1980) Pleistocene Mammals of North America. Columbia University Press, New York, 442 pp.

Librado P and Rozas J (2009) DnaSP ver. 5: A software for comprehensive analysis of DNA polymorphism data. Bioinform Appl Note 25:1451-1452.

Logan KA and Sweanor LL (2001) Desert puma: evolutionary ecology and conservation of an enduring carnivore. Island Press, Washington, D.C., 470 pp.

Maehr DS, Land ED, Shindle DB, Bass OL and Hoctor TS (2002) Florida panther dispersal and conservation. Biol Conserv 106:187-197.

Mantel N (1967) The detection of disease clustering and a generalized regression approach. Cancer Res 27:209-220.

Miller MP (2005) Alleles in Space (AIS): Computer software for the joint analysis of interindividual spatial and genetic information. J. Hered 96:722-724.

Miotto RA, Cervini M, Figueiredo MG, Begotti RA and Galetti Jr PM (2011) Genetic diversity and population structure of pumas (Puma concolor) in southeastern Brazil: Implications for conservation in a human-dominated landscape. Conserv Genet 12:1447-1455.

Miotto RA, Cervini M, Begotti RA and Galetti Jr PM (2012) Monitoring a puma (Puma concolor) population in a fragmented landscape in southeast Brazil. Biotropica 44:98-104.

Nowak RM (1999) Walker's Mammals of the World. Vol. 2. 6th ed. The Johns Hopkins University Press, Baltimore, pp 818-820.

O'Brien SJ, Roelke M, Yuhki N, Richards KW, Johnson WE, Franklin WL, Anderson AE, Bass Jr OL, Belden RC and Martenson JS (1990) Genetic introgression within the Florida Panther Felis concolor coryi. Natl Geogr Res 6:485494.

Olson DM, Dinerstein E, Wikramanayake ED, Burgess ND, Powell GVN, Underwood EC, D'Amico JA, Itoua I, Strand HE, Kassem KR, et al. (2001) Terrestrial ecoregions of the World: A new map of life on earth. BioScience 51:933-938.

Posada D (2008) jModelTest: Phylogenetic model averaging. Mol Biol Evol 25:1253-1256. 
Pusey AE and Packer C (1987) The evolution of sex-biased dispersal in lions. Behaviour 101:275-310.

Redford KH and Eisenberg JF (1992) Mammals of the Neotropics. Vol. 2, The Southern Cone. University of Chicago Press, Chicago, 460 pp.

Rogers AR and Harpending H (1992) Population growth makes waves in the distribution of pairwise genetic differences. Mol Biol Evol 9:552-569.

Ruiz-García M, Pacheco LF and Álverez D (2009) Genetic characterization of the Bolivian Andean puma (Puma concolor) at the Sajama National Park (SNP) and relationships with other north-western South American puma populations. Rev Chil Hist Nat 82:97-117.

Ruiz-García M and Pinedo-Castro MO (2010) Molecular systematics and phylogeography of the genus Lagothrix (Atelidae, Primates) by means of the mitochondrial COII gene. Folia Primatol 81:109-128.

Ruiz-García M, Vásquez C, Pinedo-Castro MO, Sandoval S, Castellanos A, Kaston F, Thoisy B and Shostell J (2012) Phylogeography of the Mountain Tapir (Tapirus pinchaque) and the Central American Tapir (Tapirus bairdii) and the origins of the three Latin-American tapirs by means of mtCyt-B sequences. In: Anamthawat-Jónsson K (ed) Current Topics in Phylogenetics and Phylogeography of Terrestrial and Aquatic Systems. InTech, Rijeka, pp 83-116.

Ruiz-Garcia M, Vásquez C, Murillo A, Pinedo-Castro M and Alvarez D (2013) Population genetics and phylogeography of the largest wild cat in the Americas: An analysis of the jaguar by means of microsatellites and mitochondrial gene sequences. In: Ruiz-García M and Shostell J (eds) Molecular Population Genetics, Evolutionary Biology and Biological Conservation of the Neotropical Carnivores. Nova Science Publishers Inc, New York, pp 413-464.

Saiki RK, Scharf S, Fallona F, Mullis KB, Horn GT, Erlich HA and Arnheim N (1985) Enzymatic amplification of B-globin genomic sequences and restriction site analysis for diagnosis of sickle-cell anemia. Science 230:1350-1354.

Sambrook E, Fritsch F and Maniatis T (1989) Molecular Cloning. 2nd edition. Cold Spring Harbor Press, Cold Spring Harbor, New York.

Schneider S and Excoffier L (1999) Estimation of past demographic parameters from the distribution of pairwise differences when the mutation rates vary among sites: Application to human mitochondrial DNA. Genetics 152:1079-1089.

Smith JLD (1993) The role of dispersal in structuring the Chitwan tiger population. Behaviour 124:165-195.

Tamura K, Dudley J, Nei M and Kumar S (2007) MEGA4: Molecular Evolutionary Genetics Analysis (MEGA) Software ver. 4.0. Mol Biol Evol 24:1596-1599.

Tchaicka L, Eizirik E, Oliveira TG, Candido Jr F and Freitas TRO (2007) Phylogeography and population history of the crabeating fox (Cerdocyon thous). Mol Ecol 16:819-838.
Thoisy B, Silva AG, Ruiz-García M, Tapia A, Ramirez O, Arana M, Quse V, Paz-y-Miño C, Tobler M, Pedraza C, et al. (2010) Population history, phylogeography, and conservation genetics of the last Neotropical mega-herbivore, the lowland tapir (Tapirus terrestris) BMC Evol Biol 10:e278.

Trigo TC, Freitas TRO, Kunzler G, Cardoso L, Silva JCR, Johnson WE, O'Brien SJ, Bonatto SL and Eizirik E (2008) Inter-species hybridization among Neotropical cats of the genus Leopardus, and evidence for an introgressive hybrid zone between L. geoffroyi and L. tigrinus in southern Brazil. Mol Ecol 17:4317-4333.

Trinca CS, De Thoisy B, Rosas FCW, Waldemarin HF, Koepfli KP, Vianna JA and Eizirik E (2012) Phylogeography and demographic history of the Neotropical otter (Lontra longicaudis). J. Hered 103:479-492.

Woodburne MO (2010) The great american biotic interchange: Dispersals, tectonics, climate, sea level and holding pens. J Mammal Evol 17:245-264.

\section{Internet Resources}

IBGE, Instituto Brasileiro de Geografia e Estatística, http://www.ibge.gov.br (April 30, 2012).

Chromas Lite ver. 2.01 Program (http://www.technelysium.com.au) (March 12, 2011).

FinchTV ver. 1.4.0 Program (http://www.geospiza.com) (March 12, 2011).

Network ver. 4.5.1.6 Program (www.fluxus-engineering.com) (April 3, 2011).

\section{Supplementary Material}

The following online material is available for this article:

Table S1-Geographic locales included in this study.

Table S2 - Puma concolor samples analyzed in this study.

Table S3 - Nucleotide and gene diversity levels observed in Puma concolor mtDNA ND5 sequences.

Table S4 - Pairwise $\Phi$ st values among subcontinental groups of Puma concolor.

Table S5 - Pairwise $\Phi$ st values among seven major groups of Puma concolor.

Figure S1 - Graph depicting the correlation between genetic and geographic distances calculated for $P$. concolor ND5 mtDNA sequences.

This material is available as part of the online article from http://www.scielo.br/gmb

Associate Editor: Fabrício Rodrigues dos Santos

License information: This is an open-access article distributed under the terms of the Creative Commons Attribution License, which permits unrestricted use, distribution, and reproduction in any medium, provided the original work is properly cited. 
Table S1 - Geographic locales included in this study, including the individuals sampled at each site, and the source of the biological material analyzed here.

\begin{tabular}{|c|c|c|c|c|}
\hline Site Name (Region, Country) & $\begin{array}{l}\text { No. of } \\
\text { individuals }\end{array}$ & Sample IDs & \multicolumn{2}{|c|}{$\begin{array}{lc}\text { Geographic } & \text { Coordinates Contact and/or } \\
\text { (Lat/Long) } & \text { Institution }\end{array}$} \\
\hline British Columbia, Canada & 3 & Pco242, Pco258, Pco357 & $54.9,-124.5$ & LGD/NCI \\
\hline Oregon, USA & 1 & Pco007 & $43.935833,-120.575$ & LGD/NCI \\
\hline Idaho, USA & 1 & $P \cos 340$ & $43.7,-116$ & LGD/NCI \\
\hline Yellowstone National Park, USA & 2 & Pco372, Pco377 & $44.460556,-110.827778$ & LGD/NCI \\
\hline Texas, USA & 4 & $\begin{array}{l}\text { Pco036, Pco037, Pco128, } \\
\text { Pco356 }\end{array}$ & $25.833333,-93.516667$ & LGD/NCI \\
\hline Florida, USA & 2 & Pco077, Pco348 & $24.5,-79.8$ & LGD/NCI \\
\hline El Petén, Guatemala & 2 & Pco556, Pco446 & $16.9,-89.9$ & LGD/NCI \\
\hline Northern Central Guatemala & 1 & Pco555 & $15.5,-90.25$ & LGD/NCI \\
\hline Southern Guatemala & 1 & Pco557 & $15.5,-90.25$ & LGD/NCI \\
\hline Granada, Nicaragua & 1 & Pco549 & 11.933333,-85.95 & LGD/NCI \\
\hline Chontales, Nicaragua & 1 & Pco550 & $12.083333,-85.4$ & LGD/NCI \\
\hline Matagalpa, Nicaragua & 1 & Pco552 & $12.916667,-85.916667$ & LGD/NCI \\
\hline Northern Nicaragua & 2 & Pco554, Pco551 & $12.904167,-84.921944$ & LGD/NCI \\
\hline Nueva Guinea, Nicaragua & 1 & Pco553 & $11.683333,-84.45$ & LGD/NCI \\
\hline Costa Rica & 4 & $\begin{array}{l}\text { Pco545, Pco547, Pco548, } \\
\text { Pco546 }\end{array}$ & $10,-84$ & LGD/NCI \\
\hline Guanacaste, Costa Rica & 1 & Pco544 & $10.433333,-85.4$ & LGD/NCI \\
\hline Darién, Panama & 2 & Pco541, Pco542 & $8.408333,-77.915$ & LGD/NCI \\
\hline Falcón, Venezuela & 2 & Pco704, Pco703 & $8,-66$ & LGD/NCI \\
\hline Barquisimeto, Venezuela & 1 & Pco705 & $10.066667,-69.316667$ & LGD/NCI \\
\hline Tefé, AM, BR & 1 & bPco358 & $-3.353889,-64.710833$ & $\begin{array}{l}\text { Diogo Faria/ } \\
\text { CETAS/IBAMA/ } \\
\text { Pró-Carnívoros }\end{array}$ \\
\hline Presidente Figueiredo, AM, BR & 1 & bPco342 & $-2.017222,-60.025$ & $\begin{array}{l}\text { Diogo Faria/ } \\
\text { CETAS/IBAMA/ } \\
\text { Pró-Carnívoros }\end{array}$ \\
\hline Rio Preto da Eva, AM, BR & 1 & bPco343 & $-2.698889,-59.7$ & $\begin{array}{l}\text { Diogo Faria/ } \\
\text { CETAS/IBAMA/ } \\
\text { Pró-Carnívoros }\end{array}$ \\
\hline Antofagasta, Chile & 1 & Pco214 & $-24.616667,-69.533333$ & LGD/NCI \\
\hline Vicuña, Chile & 1 & Pco208 & $-33,-71.516667$ & LGD/NCI \\
\hline Ovalle, Chile & 2 & Pco207, Pco215 & $-30.6,-71.2$ & LGD/NCI \\
\hline Mendoza, Argentina & 3 & Pco570, Pco573 & $-32.88,-69.00$ & LGD/NCI \\
\hline Santiago, Chile/ Mendoza, Argentina & 10 & $\begin{array}{l}\text { Pco201, Pco209, Pco210, } \\
\text { Pco211, Pco212, Pco216, } \\
\text { Pco217, Pco564, Pco570, } \\
\text { Pco573 }\end{array}$ & $-33.073131,-70.059814$ & LGD/NCI \\
\hline Angol/Coñaripe, Chile & 1 & Pco213 & $-32.653056,-70.011944$ & LGD/NCI \\
\hline Villarica, Chile & 1 & Pco218 & $-39.266667,-72.216667$ & LGD/NCI \\
\hline $\begin{array}{l}\text { Torres Del Paine National Park, } \\
\text { Chile }\end{array}$ & 1 & Pco200 & $-50.983056,-72.966389$ & LGD/NCI \\
\hline Punta Arenas, Chile & 1 & Pco202 & $-53.15,-70.916667$ & LGD/NCI \\
\hline Chubut, Argentina & 1 & Pco567 & $-45.8,-67.5333$ & LGD/NCI \\
\hline La Pampa, Argentina & 1 & Pco565 & $-36.833333,-66$ & LGD/NCI \\
\hline Cordoba, Argentina & 1 & Pco577 & $-31.416667,-64.183333$ & LGD/NCI \\
\hline Northern Argentina & 1 & Pco562 & $-23.408333,-64.427778$ & LGD/NCI \\
\hline Uruguay & 2 & Pco580, Pco582 & $-31.683333,-55.416667$ & LGD/NCI \\
\hline Chaco, Paraguay & 3 & Pco699, Pco701, Pco581 & $-23.0,-58.0$ & LGD/NCI \\
\hline Potosí, Bolivia & 3 & Pco706, Pco709, Pco710 & $-19.583333,-65.75$ & LGD/NCI \\
\hline Santa Cruz, Bolivia & 2 & Pco707, Pco708 & $-17.8,-63.166667$ & LGD/NCI \\
\hline Ponta Porã, MS, BR & 2 & bPco327, bPco039 & $-22.535833,-55.725833$ & Ronaldo Morato/ \\
\hline
\end{tabular}




\begin{tabular}{|c|c|c|c|c|}
\hline & & & & Pró-Carnívoros \\
\hline Jardim, MS, BR & 2 & bPco035, bPco040 & $-21.48,-56.137778$ & $\begin{array}{l}\text { Ronaldo Morato/ } \\
\text { Pró-Carnívoros }\end{array}$ \\
\hline Miranda, MS, BR & 3 & bPco063, bPco064, bPco062 & $-20.240833,-56.377778$ & $\begin{array}{l}\text { Fernando Azevedo/ } \\
\text { Projeto Gadonça }\end{array}$ \\
\hline Corumbá, MS, BR & 2 & bPco037, bPco038 & $-19.008889,-57.652778$ & $\begin{array}{l}\text { Ronaldo Morato/ } \\
\text { Pró-Carnívoros }\end{array}$ \\
\hline Corguinho, MS, BR & 1 & bPco326 & $-19.831944,-54.828889$ & $\begin{array}{l}\text { Roberta Humberg/ } \\
\text { CRAS }\end{array}$ \\
\hline Barão de Melgaço, MT, BR & 11 & $\begin{array}{l}\text { bPco024, bPco025, bPco029, } \\
\text { bPco031, bPco032, bPco026, } \\
\text { bPco027, bPco028, bPco030, } \\
\text { bPco033, bPco036 }\end{array}$ & $-16.278889,-55.957778$ & $\begin{array}{l}\text { Rodrigo Jorge/ } \\
\text { Pró-Carnívoros }\end{array}$ \\
\hline Alta Floresta, MT, BR & 1 & bPco041 & $-9.875556,-56.086111$ & $\begin{array}{l}\text { Fernanda Michalski } \\
\text { /Pró-Carnívoros }\end{array}$ \\
\hline Santarém, PA, BR & 1 & bPco082 & $-2.442778,-54.707778$ & Glaucia Pontes \\
\hline Guaramiranga, CE, BR & 1 & bPco069 & $-4.262778,-38.932778$ & $\begin{array}{l}\text { Marcos Renato } \\
\text { Mattos }\end{array}$ \\
\hline Quixeramobim, CE, BR & 1 & bPco070 & $-5.198889,-39.292778$ & $\begin{array}{l}\text { Marcos Renato } \\
\text { Mattos }\end{array}$ \\
\hline Campina Grande, PB, BR & 1 & Pco700 & $-7.230556,-35.881111$ & LGD/NCI \\
\hline Araguaína, TO, BR & 1 & Pco601 & $-7.190833,-48.206944$ & LGD/NCI \\
\hline São Geraldo Araguaia, PA & 1 & bPco346 & $-6.400833,-48.555$ & $\begin{array}{l}\text { Joares May/ Inst. } \\
\text { Biotrópicos }\end{array}$ \\
\hline Araguaia, GO, BR & 1 & Pco697 & $-13.275,-50.162778$ & LGD/NCI \\
\hline Chapada Gaúcha, MG, BR & 2 & bPco337; bPco338 & $-15.305833,-45.617778$ & $\begin{array}{l}\text { Joares May, Edsel } \\
\text { Amorim Jr/ Inst. } \\
\text { Biotrópicos }\end{array}$ \\
\hline Luziânia, GO, BR & 1 & bPco333 & $-16.318611,-47.78$ & COFAU \\
\hline Goiás, BR & 2 & bPco316; Pco602 & $-15.933889,-50.14$ & $\begin{array}{l}\text { Ivaldo M. Carvalho/ } \\
\text { Pró-Carnívoros; } \\
\text { LGD/NCI }\end{array}$ \\
\hline Bataguassu, MS, BR & 1 & bPco001 & $-21.713889,-52.421944$ & $\begin{array}{l}\text { Projeto Porto } \\
\text { Primavera }\end{array}$ \\
\hline MS, BR & 1 & bPco019 & $-20.442778,-54.645833$ & Pró-Carnívoros \\
\hline Anaurilândia, MS, BR & 16 & $\begin{array}{l}\text { bPco020, bPco021, bPco022, } \\
\text { bPco023, bPco044, bPco045, } \\
\text { bPco046, bPco047, bPco048, } \\
\text { bPco049, bPco054, bPco056, } \\
\text { bPco057, bPco058, bPco059, } \\
\text { bPco067, }\end{array}$ & $-22.187778,-52.717778$ & $\begin{array}{l}\text { Dênis Sana/ Pró- } \\
\text { Carnívoros }\end{array}$ \\
\hline Batayporã, MS, BR & 2 & bPco043, Pco712 & $-22.295,-53.270833$ & $\begin{array}{l}\text { Dênis Sana/ } \\
\text { Pró-Carnívoros/ } \\
\text { LGD/NCI }\end{array}$ \\
\hline Ivinhema, MS, BR & 7 & $\begin{array}{l}\text { bPco050, bPco051, bPco052, } \\
\text { bPco053, bPco055, bPco060, } \\
\text { bPco066 }\end{array}$ & $-22.305,-53.815$ & $\begin{array}{l}\text { Dênis Sana/ } \\
\text { Pró-Carnívoros }\end{array}$ \\
\hline Ilha Solteira, SP, BR & 2 & bPco319, bPco320 & $-20.432778,-51.342778$ & $\begin{array}{l}\text { Rodrigo Jorge/ } \\
\text { Pró-Carnívoros }\end{array}$ \\
\hline Porto Primavera, MS, BR & 2 & bPco002, Pco702 & $-22.58,-53.058889$ & LGD/NCI \\
\hline Bataguassu, MS, BR & 1 & bPco042 & $-21.713889,-52.421944$ & $\begin{array}{l}\text { Dênis Sana/ } \\
\text { Pró-Carnívoros }\end{array}$ \\
\hline $\begin{array}{l}\text { Parque Nacional do Monte Pascoal, } \\
\text { Porto Seguro, BA, BR }\end{array}$ & 1 & bPco349 & $-16.45,-39.065$ & Sandra Becker \\
\hline Centralina, MG, BR & 1 & bPco071 & $-18.583889,-49.198889$ & $\begin{array}{l}\text { Frederico Genésio } \\
\text { Lemos and Hugo C. } \\
\text { M. Costa }\end{array}$ \\
\hline P. E. Cantareira, SP, BR & 1 & bPco034 & $-23.318889,-46.586944$ & Pró-Carnívoros \\
\hline Extrema, MG, BR & 1 & bPco331 & $-22.855,-46.317778$ & Pró-Carnívoros \\
\hline Getulina, SP, BR & 1 & bPco351 & $-21.798889,-49.928889$ & $\begin{array}{l}\text { Alexandre Vogliotti } \\
\text { and Javier A. } \\
\text { /NUPECCE }\end{array}$ \\
\hline Cananéia, SP, BR & 1 & bPco014 & $-25.015,-47.926944$ & Fábio Olmos \\
\hline Analândia, SP, BR & 2 & bPco317, Pco dot-d25 & $-22.125833,-47.662778$ & $\begin{array}{l}\text { Renata Miotto/ } \\
\text { UFSCar }\end{array}$ \\
\hline
\end{tabular}




\begin{tabular}{|c|c|c|c|c|}
\hline Rio Claro/Iracemápolis, SP, BR & 1 & Pco dot-d23 & $-22.540278,-47.593611$ & $\begin{array}{l}\text { Renata Miotto/ } \\
\text { UFSCar }\end{array}$ \\
\hline Paulínia, SP, BR & 1 & Pco dot-d45 & $-22.761111,-47.154167$ & $\begin{array}{l}\text { Renata Miotto/ } \\
\text { UFSCar }\end{array}$ \\
\hline Sertãozinho, SP, BR & 1 & Pco dot-d51 & $-21.198611,-48.170278$ & $\begin{array}{l}\text { Renata Miotto/ } \\
\text { UFSCar }\end{array}$ \\
\hline Northwestern SP, BR & 1 & Pco599 & $-20.512778,-50.351944$ & LGD/NCI \\
\hline Ribeirão Branco, SP, BR & 1 & bPco318 & $-24.220833,-48.765833$ & $\begin{array}{l}\text { Ronaldo Morato/ } \\
\text { Pró-Carnívoros }\end{array}$ \\
\hline Itapetininga, SP, BR & 1 & bPco302 & $-23.591944,-48.052778$ & $\begin{array}{l}\text { Ronaldo Morato/ } \\
\text { Pró-Carnívoros }\end{array}$ \\
\hline Ribeirão Preto, SP, BR & 1 & bPco332 & $-21.177778,-47.81$ & $\begin{array}{l}\text { Jorge Bin/ } \\
\text { Pró-Carnívoros }\end{array}$ \\
\hline Itirapina, SP, BR & 1 & Pco dot-d29 & $-22.240556,-47.806667$ & $\begin{array}{l}\text { Renata Miotto/ } \\
\text { UFSCar }\end{array}$ \\
\hline Itirapina, SP, BR & 1 & Pco dot-d99 & $-22.351944,-47.915278$ & $\begin{array}{l}\text { Renata Miotto/ } \\
\text { UFSCar }\end{array}$ \\
\hline Matão, SP, BR & 1 & Pco dot-d42 & $-21.585833,-48.446944$ & $\begin{array}{l}\text { Renata Miotto/ } \\
\text { UFSCar }\end{array}$ \\
\hline Catanduva, SP, BR & 1 & Pco dot-d43 & $-21.142222,-49.00833$ & $\begin{array}{l}\text { Renata Miotto/ } \\
\text { UFSCar }\end{array}$ \\
\hline Cajuru, SP,BR & 1 & Pco dot-d44 & $-21.17,-47.294167$ & $\begin{array}{l}\text { Renata Miotto/ } \\
\text { UFSCar }\end{array}$ \\
\hline Araraquara, SP, BR & 1 & Pco dot-d70 & $-21.736389,-48.170278$ & $\begin{array}{l}\text { Renata Miotto/ } \\
\text { UFSCar }\end{array}$ \\
\hline Ibirarema, SP, BR & 1 & bPco315 & $-22.817778,-50.072778$ & $\begin{array}{l}\text { Elizeu P. Ribeiro/ } \\
\text { IBAMA }\end{array}$ \\
\hline Londrina, PR, BR & 1 & bPco080 & $-23.31,-51.162778$ & Fernando Jerep \\
\hline Blumenau, SC, BR & 2 & $\mathrm{PC} 26 \mathrm{cc}, \mathrm{PC} 27 \mathrm{cc}$ & $-26.908889,-49.072222$ & $\begin{array}{l}\text { Camila S. Castilho/ } \\
\text { Projeto Leão Baio }\end{array}$ \\
\hline Lages, SC, BR & 6 & $\begin{array}{l}\text { PC08cc, PC10cc, PC15cc, } \\
\text { PC } 18 c c, \text { PC19cc, PC } 23 c c\end{array}$ & $-27.815833,-50.325833$ & $\begin{array}{l}\text { Camila S. Castilho/ } \\
\text { Projeto Leão Baio }\end{array}$ \\
\hline Ponta Alta, SC, BR & 1 & PC11cc & $-27.484167,-50.380278$ & $\begin{array}{l}\text { Camila S. Castilho/ } \\
\text { Projeto Leão Baio }\end{array}$ \\
\hline São Joaquim, SC, BR & 2 & PC20cc, PC49cc & $-28.293889,-49.931667$ & $\begin{array}{l}\text { Camila S. Castilho/ } \\
\text { Projeto Leão Baio }\end{array}$ \\
\hline Urubici, SC, BR & 6 & $\begin{array}{l}\mathrm{PC} 01 \mathrm{cc}, \mathrm{PC} 03 \mathrm{cc}, \mathrm{PC} 04 \mathrm{cc}, \\
\mathrm{PC} 06 \mathrm{cc}, \mathrm{PC} 07 \mathrm{cc}, \mathrm{PC} 22 \mathrm{cc}\end{array}$ & $-28.015000,-49.591667$ & $\begin{array}{l}\text { Camila S. Castilho/ } \\
\text { Projeto Leão Baio }\end{array}$ \\
\hline
\end{tabular}

$\mathrm{USA}=$ United States of America, $\mathrm{BR}=$ Brazil, $\mathrm{AM}=$ Amazonas State, $\mathrm{BA}=$ Bahia State, $\mathrm{CE}=$ Ceará State, $\mathrm{GO}=$ Goiás State, $\mathrm{MG}=$ Minas Gerais State, $\mathrm{MS}=$ Mato Grosso do Sul State, MT= Mato Grosso State, $\mathrm{PA}=$ Pará State, $\mathrm{PB}=$ Paraíba State, $\mathrm{PR}=$ Paraná State, $\mathrm{SC}=$ Santa Catarina State, SP= São Paulo State. LGD/NCI: Laboratory of Genomic Diversity, National Cancer Institute, USA; CETAS: Centro de Triagem de Animais Silvestres; COFAU: Coordenação de Proteção de Espécies da Fauna; CRAS: Centro de Reabilitação de Animais Silvestres; IBAMA: Instituto Brasileiro do Meio Ambiente e dos Recursos Naturais Renováveis; NUPECCE: Núcleo de Pesquisa e Conservação em Cervídeos. 
Table S2 - Puma concolor samples analyzed in this study, including their locale of origin, biome (South American samples only), ND5 haplotype and affiliation in the geographic groups defined by the AMOVA (see text for details).

\begin{tabular}{|c|c|c|c|c|}
\hline Individual & Sampling Locale & Biome & Haplotype & $\begin{array}{l}\text { AMOVA } \\
\text { group }\end{array}$ \\
\hline bPco001 & Bataguassu, MS, BR & Atlantic Forest & H01 & CNESA \\
\hline bPco002 & $\begin{array}{c}\text { Usina de Porto Primavera, } \\
\text { MS, BR } \\
\end{array}$ & Atlantic Forest & H02 & CNESA \\
\hline bPco014 & Cananéia, SP, BR & Atlantic Forest & $\mathrm{H} 03$ & ESA \\
\hline bPco019 & MS, BR & Atlantic Forest / Cerrado/ Pantanal & H01 & CNESA \\
\hline bPco020 & Anaurilândia, MS, BR & Atlantic Forest & $\mathrm{H} 02$ & CNESA \\
\hline bPco021 & Anaurilândia, MS, BR & Atlantic Forest & $\mathrm{H} 01$ & CNESA \\
\hline bPco022 & Anaurilândia, MS, BR & Atlantic Forest & H14 & CNESA \\
\hline bPco023 & Anaurilândia, MS, BR & Atlantic Forest & H01 & CNESA \\
\hline bPco024 & Barão de Melgaço, MT, BR & Pantanal & $\mathrm{H} 02$ & CNESA \\
\hline bPco025 & Pantanal - MT, BR & Pantanal & H02 & CNESA \\
\hline bPco026 & Barão de Melgaço, MT, BR & Pantanal & H03 & CNESA \\
\hline bPco027 & Barão de Melgaço, MT, BR & Pantanal & $\mathrm{H} 21$ & CNESA \\
\hline bPco028 & Pantanal, MT, BR & Pantanal & $\mathrm{H} 21$ & CNESA \\
\hline bPco029 & Barão de Melgaço, MT, BR & Pantanal & $\mathrm{H} 02$ & CNESA \\
\hline bPco030 & Barão de Melgaço, MT, BR & Pantanal & $\mathrm{H} 21$ & CNESA \\
\hline bPco031 & Barão de Melgaço, MT, BR & Pantanal & $\mathrm{H} 02$ & CNESA \\
\hline bPco032 & Pantanal, MT, BR & Pantanal & H02 & CNESA \\
\hline bPco033 & Pantanal, MT, BR & Pantanal & H06 & CNESA \\
\hline bPco034 & PE Cantareira, SP, BR & Atlantic Forest & H01 & CNESA \\
\hline bPco035 & Jardim, MS, BR & Cerrado & H07 & CNESA \\
\hline bPco036 & Pantanal - MS ou MT, BR & Pantanal & H06 & CNESA \\
\hline bPco037 & Corumbá, MS, BR & Pantanal & H05 & CSSA \\
\hline bPco038 & Corumbá, MS, BR & Pantanal & H05 & CSSA \\
\hline bPco039 & Ponta Porã, MS, BR & Cerrado & H09 & CNESA \\
\hline bPco040 & Jardim, MS, BR & Cerrado & $\mathrm{H} 10$ & CNESA \\
\hline bPco041 & Alta Floresta, MT, BR & Amazon Forest & H11 & CNESA \\
\hline
\end{tabular}




\begin{tabular}{|c|c|c|c|c|}
\hline bPco042 & Bataguassu, MS, BR & Atlantic Forest & $\mathrm{H} 02$ & CNESA \\
\hline bPco043 & Batayporã, MS, BR & Atlantic Forest & H01 & CNESA \\
\hline bPco044 & Anaurilândia, MS, BR & Atlantic Forest & H01 & CNESA \\
\hline bPco045 & Anaurilândia, MS, BR & Atlantic Forest & H01 & CNESA \\
\hline bPco046 & Anaurilândia, MS, BR & Atlantic Forest & $\mathrm{H} 02$ & CNESA \\
\hline bPco047 & Anaurilândia, MS, BR & Atlantic Forest & H07 & CNESA \\
\hline bPco048 & Anaurilândia, MS, BR & Atlantic Forest & $\mathrm{H} 10$ & CNESA \\
\hline bPco049 & Anaurilândia, MS, BR & Atlantic Forest & H01 & CNESA \\
\hline bPco050 & Ivinhema, MS, BR & Atlantic Forest & $\mathrm{H} 10$ & CNESA \\
\hline bPco051 & Ivinhema, MS, BR & Atlantic Forest & $\mathrm{H} 10$ & CNESA \\
\hline bPco052 & Ivinhema, MS, BR & Atlantic Forest & $\mathrm{H} 10$ & CNESA \\
\hline bPco053 & Ivinhema, MS, BR & Atlantic Forest & H01 & CNESA \\
\hline bPco054 & Anaurilândia, MS, BR & Atlantic Forest & H09 & CNESA \\
\hline bPco055 & Ivinhema, MS, BR & Atlantic Forest & H14 & CNESA \\
\hline bPco056 & Anaurilândia, MS, BR & Atlantic Forest & H01 & CNESA \\
\hline bPco057 & Anaurilândia, MS, BR & Atlantic Forest & H09 & CNESA \\
\hline bPco058 & Anaurilândia, MS, BR & Atlantic Forest & $\mathrm{H} 10$ & CNESA \\
\hline bPco059 & Anaurilândia, MS, BR & Atlantic Forest & $\mathrm{H} 10$ & CNESA \\
\hline bPco060 & Ivinhema, MS, BR & Atlantic Forest & H07 & CNESA \\
\hline bPco062 & Miranda_MS_BR & Pantanal & $\mathrm{H} 12$ & CSSA \\
\hline bPco063 & Miranda_MS_BR & Pantanal & H07 & CSSA \\
\hline bPco064 & Miranda_MS_BR & Pantanal & $\mathrm{H} 12$ & CSSA \\
\hline bPco066 & Ivinhema, MS, BR & Atlantic Forest & H01 & CNESA \\
\hline bPco067 & Anaurilândia, MS, BR & Atlantic Forest & H09 & CNESA \\
\hline bPco069 & Guaramiranga, CE, BR & Caatinga (Xeric Shrublands) & H13 & CNESA \\
\hline bPco070 & Quixeramobim, CE, BR & Caatinga (Xeric Shrublands) & $\mathrm{H} 13$ & CNESA \\
\hline bPco071 & Centralina, MG, BR & Atlantic Forest & H03 & ESA \\
\hline bPco080 & Londrina, PR, BR & Atlantic Forest & H09 & CNESA \\
\hline bPco082 & Santarém, PA, BR & Amazon Forest & $\mathrm{H} 22$ & CNESA \\
\hline bPco302 & Itapetininga, SP, BR & Atlantic Forest / & H04 & CNESA \\
\hline
\end{tabular}




\begin{tabular}{|c|c|c|c|c|}
\hline & & Cerrado & & \\
\hline bPco315 & Ibirarema, SP, BR & Atlantic Forest & $\mathrm{H} 02$ & CNESA \\
\hline bPco316 & GO, BR & Cerrado & H09 & CNESA \\
\hline bPco317 & Analândia, SP, BR & Cerrado & $\mathrm{H} 02$ & CNESA \\
\hline bPco318 & Ribeirão Branco,SP, BR & Atlantic Forest & H09 & CNESA \\
\hline bPco319 & SP, BR & Atlantic Forest & H01 & CNESA \\
\hline bPco320 & $\mathrm{SP}, \mathrm{BR}$ & Atlantic Forest & $\mathrm{H} 02$ & CNESA \\
\hline bPco326 & Corguinho, MS, BR & Atlantic Forest & H09 & CSSA \\
\hline bPco327 & Ponta Porã, MS, BR & Cerrado & H06 & CNESA \\
\hline bPco331 & Extrema, MG, BR & Atlantic Forest & H01 & CNESA \\
\hline bPco332 & Ribeirão Preto,SP, BR & Cerrado & H15 & ESA \\
\hline bPco333 & Luziânia, GO, BR & Cerrado & H02 & CNESA \\
\hline bPco337 & Chapada Gaúcha, MG, BR & Cerrado & H02 & CNESA \\
\hline bPco338 & Chapada Gaúcha_MG_BR & Cerrado & H02 & CNESA \\
\hline bPco342 & $\begin{array}{c}\text { Presidente Figueiredo, AM, } \\
\text { BR }\end{array}$ & Amazon Forest & H16 & NSA \\
\hline bPco343 & Rio Preto da Eva, AM, BR & Amazon Forest & H16 & NSA \\
\hline bPco346 & $\begin{array}{c}\text { São Geraldo do Araguaia, } \\
\text { PA }\end{array}$ & Amazon Forest & H17 & CNESA \\
\hline bPco349 & $\begin{array}{c}\text { ParNA Montel Pascoal, BA, } \\
\text { BR }\end{array}$ & Atlantic Forest & H03 & ESA \\
\hline bPco351 & Getulina, SP, BR & Atlantic Forest & H02 & CNESA \\
\hline bPco358 & Tefé, AM, BR & Amazon Forest & H16 & NSA \\
\hline $\mathrm{d} 23$ & Rio Claro, SP, BR & Atlantic Forest & H02 & CNESA \\
\hline $\mathrm{d} 25$ & Analândia, SP, BR & Cerrado & $\mathrm{H} 02$ & CNESA \\
\hline d29 & Itirapina, SP, BR & Cerrado & H15 & CNESA \\
\hline $\mathrm{d} 42$ & Matão, SP, BR & Cerrado & H15 & ESA \\
\hline $\mathrm{d} 43$ & Catanduva, SP, BR & Atlantic Forest & H15 & ESA \\
\hline $\mathrm{d} 44$ & Cajuru, SP, BR & Atlantic Forest / Cerrado & $\mathrm{H} 02$ & ESA \\
\hline $\mathrm{d} 45$ & Paulínia, SP, BR & Atlantic Forest & $\mathrm{H} 03$ & ESA \\
\hline d51 & Sertãozinho, SP, BR & Cerrado & H03 & CNESA \\
\hline $\mathrm{d} 70$ & Araraquara, SP, BR & Cerrado & H15 & ESA \\
\hline
\end{tabular}




\begin{tabular}{|c|c|c|c|c|}
\hline d99 & Itirapina, SP, BR & Cerrado & H15 & ESA \\
\hline PC01cc & Urubici, SC, BR & Atlantic Forest & $\mathrm{H} 02$ & CNESA \\
\hline $\mathrm{PC} 03 \mathrm{cc}$ & Urubici, SC, BR & Atlantic Forest & $\mathrm{H} 02$ & CNESA \\
\hline $\mathrm{PC} 04 \mathrm{cc}$ & Urubici, SC, BR & Atlantic Forest & $\mathrm{H} 02$ & CNESA \\
\hline $\mathrm{PC} 06 \mathrm{cc}$ & Urubici, SC, BR & Atlantic Forest & H02 & CNESA \\
\hline $\mathrm{PC} 07 \mathrm{cc}$ & Urubici, SC, BR & Atlantic Forest & $\mathrm{H} 02$ & CNESA \\
\hline $\mathrm{PC} 08 \mathrm{cc}$ & Lages, SC, BR & Atlantic Forest & H02 & CNESA \\
\hline $\mathrm{PC} 10 \mathrm{cc}$ & Lages, SC, BR & Atlantic Forest & $\mathrm{H} 02$ & CNESA \\
\hline $\mathrm{PC} 11 \mathrm{cc}$ & Ponta Alta, SC, BR & Atlantic Forest & $\mathrm{H} 02$ & CNESA \\
\hline $\mathrm{PC} 15 \mathrm{cc}$ & Lages, SC, BR & Atlantic Forest & $\mathrm{H} 10$ & CNESA \\
\hline $\mathrm{PC} 18 \mathrm{cc}$ & Lages, SC, BR & Atlantic Forest & $\mathrm{H} 10$ & CNESA \\
\hline $\mathrm{PC} 19 \mathrm{cc}$ & Lages, SC, BR & Atlantic Forest & H02 & CNESA \\
\hline $\mathrm{PC} 20 \mathrm{cc}$ & São Joaquim, SC, BR & Atlantic Forest & $\mathrm{H} 02$ & CNESA \\
\hline $\mathrm{PC} 22 \mathrm{cc}$ & Urubici, SC, BR & Atlantic Forest & $\mathrm{H} 02$ & CNESA \\
\hline $\mathrm{PC} 23 \mathrm{cc}$ & Lages, SC, BR & Atlantic Forest & $\mathrm{H} 10$ & CNESA \\
\hline $\mathrm{PC} 26 \mathrm{cc}$ & Blumenau, SC, BR & Atlantic Forest & $\mathrm{H} 10$ & CNESA \\
\hline $\mathrm{PC} 27 \mathrm{cc}$ & Blumenau, SC, BR & Atlantic Forest & H16 & CNESA \\
\hline $\mathrm{PC} 49 \mathrm{cc}$ & São Joaquim, SC, BR & Atlantic Forest & $\mathrm{H} 02$ & CNESA \\
\hline Pco007 & Oregon, USA & & $\mathrm{H} 23$ & $\mathrm{NCA}+\mathrm{NA}$ \\
\hline Pco036 & Texas, USA & & $\mathrm{H} 23$ & $\mathrm{NCA}+\mathrm{NA}$ \\
\hline Pco037 & Texas, USA & & $\mathrm{H} 23$ & $\mathrm{NCA}+\mathrm{NA}$ \\
\hline Pco077 & Florida, USA & & $\mathrm{H} 24$ & $\mathrm{NCA}+\mathrm{NA}$ \\
\hline Pco128 & Texas, USA & & $\mathrm{H} 23$ & $\mathrm{NCA}+\mathrm{NA}$ \\
\hline Pco200 & Torres Del Paine NP, Chile & Temperate grasslands and Shrublands & $\mathrm{H} 18$ & SWSA \\
\hline Pco201 & Chile & Mediterranean scrub, montane grasslands, Desert and xeric Shrublands & H18 & SWSA \\
\hline Pco202 & Punta Arenas, Chile & Patagonian Pampas (Temperate Grasslands, Savannas and Shrublands) & H18 & SWSA \\
\hline Pco207 & Ovalle, IV region, Chile & Mediterranean scrub & H19 & SWSA \\
\hline Pco208 & Vicuña, IV region, Chile & Mediterranean scrub & $\mathrm{H} 18$ & SWSA \\
\hline Pco209 & Chile & Mediterranean scrub, montane grasslands, Desert and xeric Shrublands & H19 & SWSA \\
\hline Pco210 & Chile & Mediterranean scrub, montane grasslands, Desert and xeric Shrublands & H19 & SWSA \\
\hline
\end{tabular}




\begin{tabular}{|c|c|c|c|c|}
\hline Pco211 & Chile & Mediterranean scrub, montane grasslands, Desert and xeric Shrublands & H19 & SWSA \\
\hline Pco212 & $\begin{array}{l}\text { Cordillheiras Santiago, } \\
\text { Chile/Mendoza, Argentina }\end{array}$ & Montane grasslands & $\mathrm{H} 18$ & SWSA \\
\hline Pco213 & Angol/Coñaripe, Chile & Mediterranean scrub & H18 & SWSA \\
\hline Pco214 & Antofagasta, Chile & Mediterranean scrub & $\mathrm{H} 18$ & SWSA \\
\hline Pco215 & Ovalle, Chile & Mediterranean scrub & H19 & SWSA \\
\hline Pco216 & Chile & Mediterranean scrub, montane grasslands, Desert and xeric Shrublands & H19 & SWSA \\
\hline Pco217 & Chile & Mediterranean scrub, montane grasslands, Desert and xeric Shrublands & H19 & SWSA \\
\hline Pco218 & Villarica, Chile & Mediterranean scrub & H18 & SWSA \\
\hline Pco242 & British Columbia, Canada & & $\mathrm{H} 23$ & $\mathrm{NCA}+\mathrm{NA}$ \\
\hline Pco258 & British Columbia, Canada & & $\mathrm{H} 23$ & $\mathrm{NCA}+\mathrm{NA}$ \\
\hline Pco340 & Idaho, USA & & $\mathrm{H} 23$ & $\mathrm{NCA}+\mathrm{NA}$ \\
\hline Pco348 & Florida, USA & & $\mathrm{H} 25$ & $\mathrm{NCA}+\mathrm{NA}$ \\
\hline Pco356 & Texas, USA & & $\mathrm{H} 23$ & $\mathrm{NCA}+\mathrm{NA}$ \\
\hline Pco357 & British Columbia, Canada & & $\mathrm{H} 23$ & $\mathrm{NCA}+\mathrm{NA}$ \\
\hline Pco372 & Yellowstone NP, USA & & $\mathrm{H} 23$ & $\mathrm{NCA}+\mathrm{NA}$ \\
\hline Pco377 & Yellowstone NP, USA & & $\mathrm{H} 23$ & $\mathrm{NCA}+\mathrm{NA}$ \\
\hline Pco446 & El Petén, Guatemala & & $\mathrm{H} 26$ & $\mathrm{NCA}+\mathrm{NA}$ \\
\hline Pco541 & Darién, Panama & & $\mathrm{H} 23$ & SCA \\
\hline Pco542 & Darién, Panama & & $\mathrm{H} 24$ & SCA \\
\hline Pco544 & Guanacaste, CostaRica & & $\mathrm{H} 23$ & $\mathrm{NCA}+\mathrm{NA}$ \\
\hline Pco545 & Costa Rica & & H09 & SCA \\
\hline Pco546 & Costa Rica & & $\mathrm{H} 24$ & SCA \\
\hline Pco547 & Costa Rica & & H09 & SCA \\
\hline Pco548 & Costa Rica & & H09 & SCA \\
\hline Pco549 & Granada, Nicaragua & & $\mathrm{H} 23$ & $\mathrm{NCA}+\mathrm{NA}$ \\
\hline Pco550 & Chontales, Nicaragua & & $\mathrm{H} 23$ & $\mathrm{NCA}+\mathrm{NA}$ \\
\hline Pco551 & Nicaragua & & $\mathrm{H} 27$ & $\mathrm{NCA}+\mathrm{NA}$ \\
\hline Pco552 & Matagalpa, Nicaragua & & $\mathrm{H} 23$ & $\mathrm{NCA}+\mathrm{NA}$ \\
\hline Pco553 & Nueva Guinea, Nicaragua & & $\mathrm{H} 26$ & $\mathrm{NCA}+\mathrm{NA}$ \\
\hline
\end{tabular}




\begin{tabular}{|c|c|c|c|c|}
\hline Pco554 & North Nicaragua & & $\mathrm{H} 23$ & $\mathrm{NCA}+\mathrm{NA}$ \\
\hline Pco555 & Central-North Guatemala & & $\mathrm{H} 26$ & $\mathrm{NCA}+\mathrm{NA}$ \\
\hline Pco556 & El Petén, Guatemala & & $\mathrm{H} 23$ & $\mathrm{NCA}+\mathrm{NA}$ \\
\hline Pco557 & Sul Guatemala & & $\mathrm{H} 28$ & $\mathrm{NCA}+\mathrm{NA}$ \\
\hline Pco562 & North Argentina & $\begin{array}{l}\text { Montane grasslands, trop. and subtrop. moist forests, trop. and subtrop. grasslands and shrublands, trop. and } \\
\text { subtrop. dry forests }\end{array}$ & H07 & CSSA \\
\hline Pco564 & $\begin{array}{l}\text { Foothills of Andes, } \\
\text { Argentina }\end{array}$ & Montane grasslands & $\mathrm{H} 07$ & SWSA \\
\hline Pco565 & La Pampa, Argentina & Patagonian Pampas (Temperate Grasslands, Savannas and Shrublands) & $\mathrm{H} 18$ & SWSA \\
\hline Pco567 & Chubut, Argentina & Patagonian Pampas (Temperate Grasslands, Savannas and Shrublands) & H07 & SWSA \\
\hline Pco570 & Mendoza, Argentina & Montane grasslands & H18 & SWSA \\
\hline Pco573 & Mendoza, Argentina & Montane grasslands & $\mathrm{H} 18$ & SWSA \\
\hline Pco577 & Córdoba, Argentina & Patagonian Pampas (Temperate Grasslands, Savannas and Shrublands) & H07 & CSSA \\
\hline Pco580 & Mercedes Zoo, Uruguay & Pampa (tropical and subtropical grasslands and shrublands) & H09 & CSSA \\
\hline Pco581 & Paraguay & Tropical and subtrop. grasslands and shrublands, trop. and subtrop. dry forest, chaco & H07 & CNESA \\
\hline Pco582 & Zoo Durazno, Uruguay & Pampa (tropical and subtropical grasslands and shrublands) & H09 & CSSA \\
\hline Pco599 & Northwest SP, BR & Atlantic Forest/ Cerrado & $\mathrm{H} 03$ & ESA \\
\hline Pco601 & Araguaína, TO, BR & Cerrado & H10 & CNESA \\
\hline Pco602 & Goiás, BR & Cerrado & H02 & CNESA \\
\hline Pco697 & Araguaia, GO, BR & Cerrado & $\mathrm{H} 02$ & CNESA \\
\hline Pco699 & Chaco Paraguay & Pantanal (Chaco) & $\mathrm{H} 02$ & CNESA \\
\hline Pco700 & Campina Grande, PB, BR & Caatinga (Xeric Shrublands) & $\mathrm{H} 02$ & CNESA \\
\hline Pco701 & Paraguay & Tropical and subtrop. grasslands and shrublands, trop. and subtrop. dry forest, chaco & H01 & CNESA \\
\hline Pco702 & $\begin{array}{l}\text { Usina de Porto Primavera, } \\
\text { MS, BR }\end{array}$ & Atlantic Forest & H15 & CNESA \\
\hline Pco703 & Venezuela & Tropical and subtrop. moist forests, trop. and subtrop. grasslands and shrublands, trop. and subtrop. dry forest & $\mathrm{H} 20$ & NSA \\
\hline Pco704 & Falcón, Venezuela & Coriano System & H16 & NSA \\
\hline Pco705 & Barquisimeto, Venezuela & Coriano System & H16 & NSA \\
\hline Pco706 & Potosí, Bolivia & Montane grasslands & H09 & CSSA \\
\hline Pco707 & Santa Cruz, Bolivia & Beni Savanna, Tropical and subtrop. dry broadleaf forest/Amazon Rainforest (trop. moist forests) & H06 & CSSA \\
\hline Pco708 & Santa Cruz, Bolivia & Tropical and subtrop. dry broadleaf forest/Amazon Rainforest (trop. moist forests) & H09 & CSSA \\
\hline
\end{tabular}




\begin{tabular}{|c|c|c|c|c|}
\hline Pco709 & Potosí, Bolivia & Montane grasslands & H09 & CSSA \\
\hline Pco710 & Potosí, Bolivia & Montane grasslands & $\mathrm{H} 08$ & CSSA \\
\hline Pco712 & Batayporã, MS, BR & Atlantic Forest & H09 & CNESA \\
\hline bPco015* & Campinas Zoo, BR & & - & - \\
\hline bPco016* & Campinas Zoo, BR & & - & - \\
\hline Pco558* & Argentina & & - & - \\
\hline Pco559* & Argentina & & - & - \\
\hline Pco560* & Argentina & & - & - \\
\hline Pco561* & Argentina & & - & - \\
\hline $\mathrm{P} \operatorname{co5} 51^{*}$ & Mendoza Zoo, Argentina & & - & - \\
\hline Pco574* & Mendoza Zoo, Argentina & & - & - \\
\hline Pco575* & Mendoza Zoo, Argentina & & - & - \\
\hline Pco578* & Cordoba Zoo, Argentina & & - & - \\
\hline Pco579* & Cordoba Zoo, Argentina & & - & - \\
\hline Pco600* & Sorocaba Zoo, SP, BR & & - & - \\
\hline
\end{tabular}

* Samples included only in general estimates of genetic diversity indices and neutrality tests. 
Table S3 - Nucleotide and gene diversity levels observed in Puma concolor mtDNA ND5 sequences, compared to estimates for Leopardus tigrinus and L. geoffroyi based on a shared 567 bp-long ND5 fragment.

\begin{tabular}{lccc}
\hline Species & $\mathrm{N}$ & $\begin{array}{c}\text { Nucleotide Diversity }( \pm \mathrm{SE}) \\
\text { per site }\end{array}$ & Gene Diversity $( \pm \mathrm{SE})$ \\
\hline $\begin{array}{l}\text { Puma concolor } \\
\text { P. concolor } \text { in the }\end{array}$ & 186 & $0.00547(0.00029)$ & $0.9200(0.008)$ \\
Neotropical ecozone & 173 & $0.00523(0.00034)$ & $0.9130(0.010)$ \\
$\begin{array}{l}\text { Leopardus tigrinus } \\
\text { L. geoffroyi }\end{array}$ & 46 & $0.00310(0.0004)$ & $0.7590(0.0450)$ \\
\hline
\end{tabular}


Table S4 - Pairwise $\Phi$ st values among subcontinental groups groups of Puma concolor, estimated on the basis of p-distances (see text for details).

\begin{tabular}{lll}
\hline & SA & SCA \\
\hline SCA & $0.61042 *$ & \\
NCA+NA & $0.12353^{*}$ & $0.63855^{*}$ \\
\hline
\end{tabular}

Obs.: * significant $\Phi s t(\mathrm{p}<0.05)$. Acronyms are as follows: SA (156 individuals): South America; SCA (6 individuals): Southern Central America; NA+ NCA (24 individuals): North America + Northern Central America. 
Table S5 - Pairwise $\Phi s t$ values among seven major groups of Puma concolor, estimated on the basis of p-distances (see text for details).

\begin{tabular}{lllllll}
\hline & NA+NCA & SCA & NSA & CNESA & ESA & CSSA \\
\hline SCA & $0.63855^{*}$ & & & & & \\
NSA & $0.83374^{*}$ & $0.32381^{*}$ & & & & \\
CNESA & $0.67477^{*}$ & $0.21589^{*}$ & $0.36745^{*}$ & & & \\
ESA & $0.89971^{*}$ & $0.67027^{*}$ & $0.95000^{*}$ & $0.71996^{*}$ & & \\
CSSA & $0.78669^{*}$ & $0.25650^{*}$ & $0.32328^{*}$ & $0.27647^{*}$ & $0.84102^{*}$ & \\
SWSA & $0.73617^{*}$ & $0.27918^{*}$ & $0.44948^{*}$ & $0.28448^{*}$ & $0.76492^{*}$ & $0.34911^{*}$ \\
\hline
\end{tabular}

Obs.: * significant $\Phi_{s t}(\mathrm{p}<0.05)$. Acronyms are as follows: NSA (6 samples): Northern South America (Northern Brazil + Venezuela); CNESA (97 samples): Central-North-Eastern South America [eastern MS + South + Northeast, Brazil]; ESA (13 samples): Eastern Brazil (SP, BA and MG); CSSA (15 samples): North-Central region of Argentina + Uruguay + Bolivia + western MS; NSWSA (20 samples): Chile + Southern and Western Argentina (20 samples); SCA (6 samples): Southern Central America (Costa Rica and Panama); NA+NCA (24 samples): North America + Northern Central America (Northern Costa Rica, Nicaragua, Guatemala, USA and Canada). 
Figure S1. Graph depicting the correlation between genetic and geographic distances calculated for $P$. concolor ND5 mtDNA sequences. (A) South America only. (B) Total sample.

A)

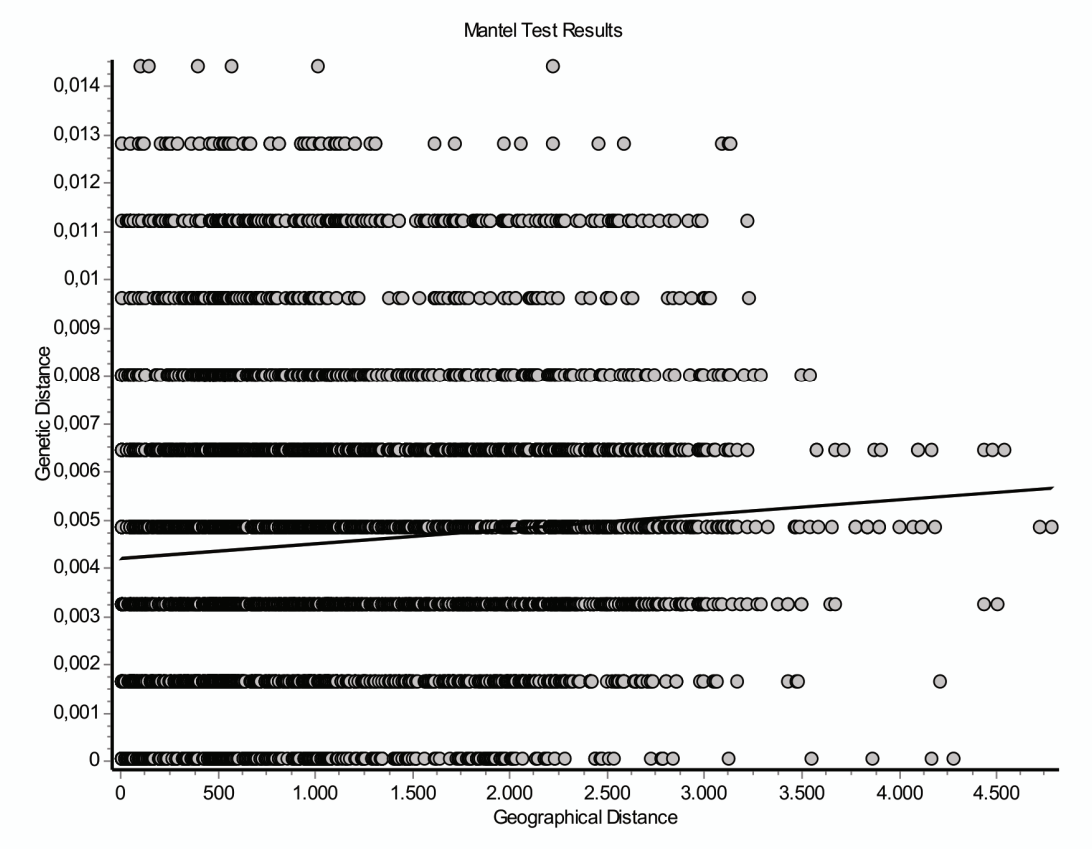

B)

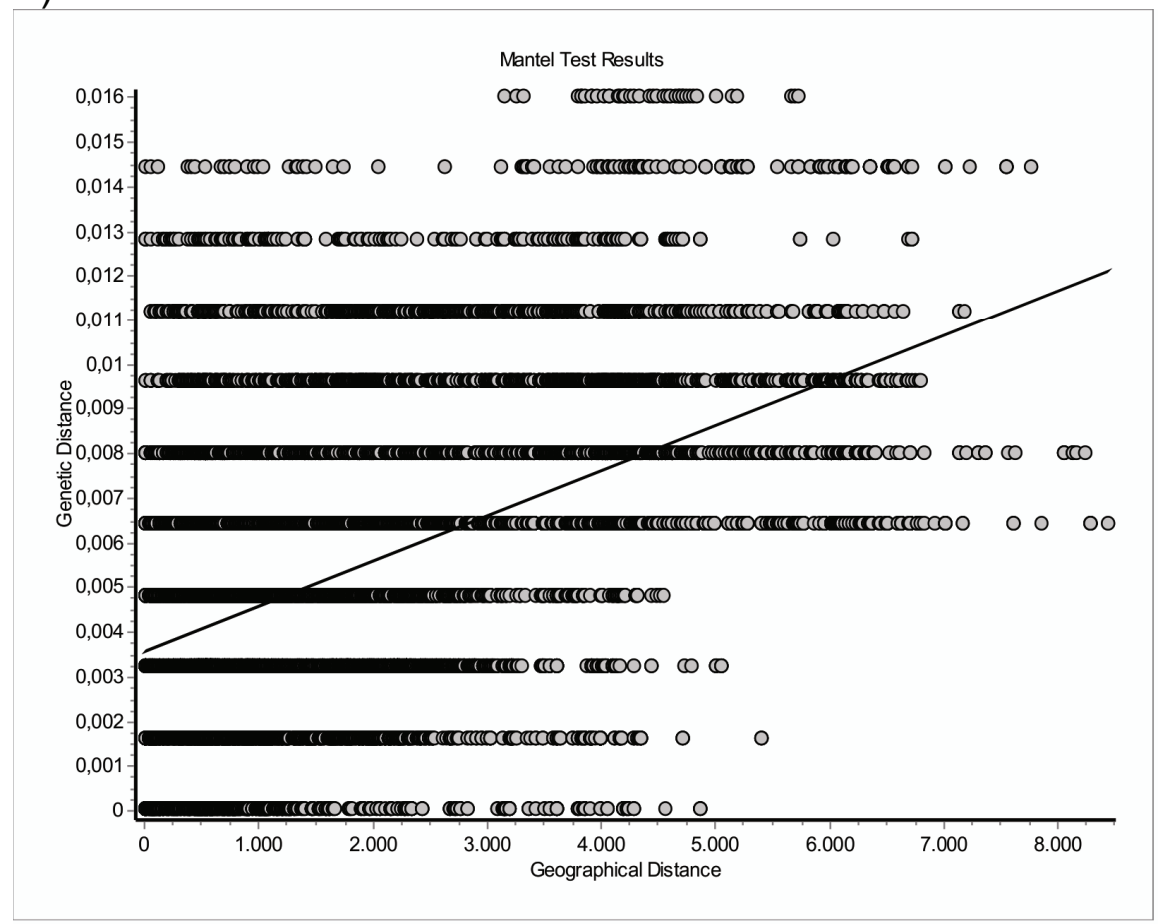

